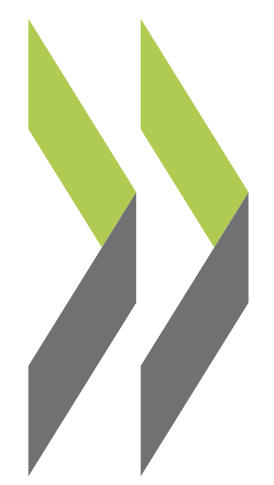

OECD Economics Department Working Papers No. 1242

\section{The economic}

consequences of an ageing population in Slovenia
Peter Walkenhorst, Urban Sila 


\section{Unclassified}

ECO/WKP(2015)60

Organisation de Coopération et de Développement Économiques

Organisation for Economic Co-operation and Development

25-Jun-2015

ECONOMICS DEPARTMENT

English - Or. English

THE ECONOMIC CONSEQUENCES OF AN AGEING POPULATION IN SLOVENIA

ECONOMICS DEPARTMENT WORKING PAPERS No. 1242

By Peter Walkenhorst and Urban Sila

OECD Working Papers should not be reported as representing the official views of the OECD or of its member countries. The opinions expressed and arguments employed are those of the author(s).

Authorised for publication by Alvaro Pereira, Director, Country Studies Branch, Economics Department.

All Economics Department Working Papers are available at www.oecd.org/eco/workingpapers

JT03379435

Complete document available on OLIS in its original format

This document and any map included herein are without prejudice to the status of or sovereignty over any territory, to the delimitation of international frontiers and boundaries and to the name of any territory, city or area. 
OECD Working Papers should not be reported as representing the official views of the OECD or of its member countries. The opinions expressed and arguments employed are those of the author(s).

Working Papers describe preliminary results or research in progress by the author(s) and are published to stimulate discussion on a broad range of issues on which the OECD works.

Comments on Working Papers are welcomed, and may be sent to the Economics Department, OECD, 2 rue André-Pascal, 75775 Paris Cedex 16, France, or by e-mail to eco.contact@oecd.org.

The statistical data for Israel are supplied by and under the responsibility of the relevant Israeli authorities. The use of such data by the OECD is without prejudice to the status of the Golan Heights, East Jerusalem and Israeli settlements in the West Bank under the terms of international law.

\section{(C) OECD (2015)}

You can copy, download or print OECD content for your own use, and you can include excerpts from OECD publications, databases and multimedia products in your own documents, presentations, blogs, websites and teaching materials, provided that suitable acknowledgment of OECD as source and copyright owner is given. All requests for commercial use and translation rights should be submitted to rights@oecd.org 


\section{Abstract/Résumé \\ The economic consequences of an ageing population in Slovenia}

Slovenia's population is set to age rapidly in the coming decades. This demographic trend will increasingly put pressure on already fragile public finances as age related expenditure is projected to rise by 3 percentage points of GDP by the year 2030. Ensuring debt sustainability and generational equity requires reforms of social support systems and necessitates adjustments in labour markets. Policy makers will thus need to act more strongly than in the past to rein in ageing related outlays, pursue efficiency-enhancing restructurings of health and long-term care systems, and adopt measures to strengthen labour force participation. In particular, further increases in the relatively low pension age in line with the rise in life expectancy would reduce pension costs and the burden on the active population. Better utilisation of medical resources and coordinated purchasing of medical supplies would curb health care expenditure, while a dedicated funding mechanism for long-term care would enhance the sustainability of the system. Moreover, removing incentives for early retirement in combination with active labour market policies would increase the labour force participation rates of older workers from its currently very low levels.

This Working Paper relates to the 2015 OECD Economic Survey of Slovenia

(www.oecd.org/eco/surveys/economic-survey-slovenia.htm).

JEL classification: H55, I1, J1

Keywords: Slovenia, pension system, health and long-term care, ageing society

\section{Les conséquences économiques d'une population vieillissante en Slovénie}

La population de la Slovénie vieillira rapidement dans les prochaines décennies. Cette tendance démographique mettra la pression de plus en plus sur les finances publiques déjà fragiles, car les dépenses liées au vieillissement devraient augmenter de 3 points de pourcentage du PIB d'ici l'an 2030. Assurer la viabilité de la dette et l'équité intergénérationnelle exige des réformes des systèmes de soutien social et nécessite des ajustements du marché du travail. Les décideurs devront donc agir plus fortement que par le passé à freiner les dépenses liées au vieillissement, de poursuivre les restructurations améliorant l'efficacité des systèmes de santé et de soins de longue durée, et d'adopter des mesures visant à renforcer la participation au marché du travail. En particulier, de nouvelles augmentations du relativement faible âge de la retraite en ligne avec la hausse de l'espérance de vie réduiraient les coûts de pension et le fardeau sur la population active. Une meilleure utilisation des ressources médicales et l'achat coordonné de fournitures médicales freinerait les dépenses de soins de santé, tandis qu'un mécanisme de financement spécifique pour les soins à long terme renforcerait la viabilité du système. En outre, la suppression des incitations à la retraite anticipée en combinaison avec les politiques du marché du travail active entraîneraient une augmentation des taux d'activité des travailleurs âgés au marché du travail de ses actuellement très faibles niveaux.

Ce Document de travail se rapporte à l'Étude économique de l'OCDE de la Slovénie, 2015 (www.oecd.org/fr/eco/etudes/etude-economique-slovenie.htm).

Classification JEL : H55, I1, J1

Mots clés : Slovénie, système de retraite, de santé et de soins de longue durée, vieillissement de la société 


\section{TABLE OF CONTENTS}

THE ECONOMIC CONSEQUENCES OF AN AGEING POPULATION IN SLOVENIA .......................5

Making the pension system sustainable requires further policy reform .................................................

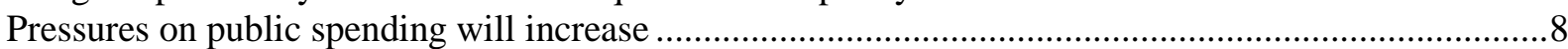

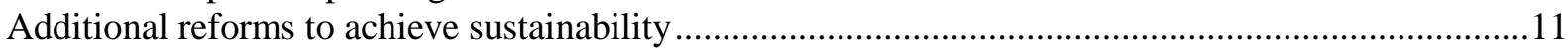

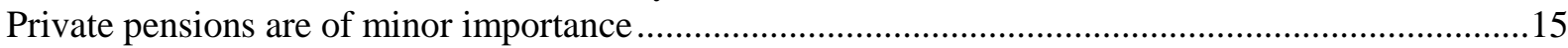

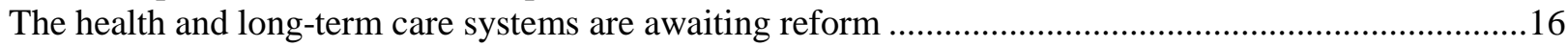

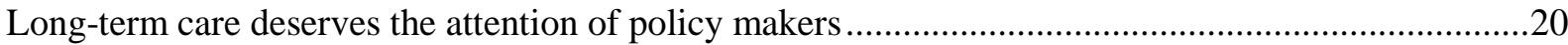

Demographic trends will have profound implications for the labour market .........................................22

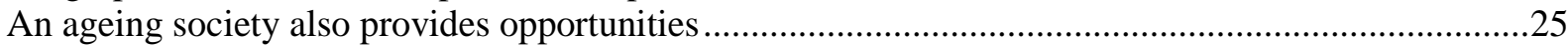

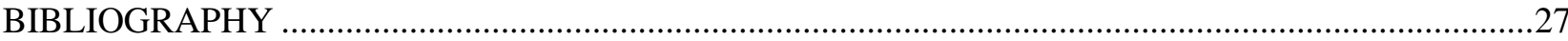

\section{Figures}

1. The population in Slovenia is ageing more rapidly than in most other OECD countries..................5

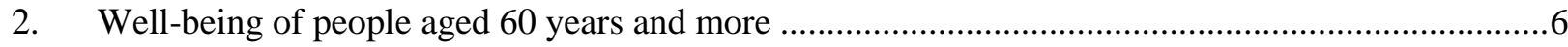

3. Age-related expenditures will exert significant pressure ...........................................................

4. Public spending for old-age and survivor pensions is relatively high in Slovenia ...........................7

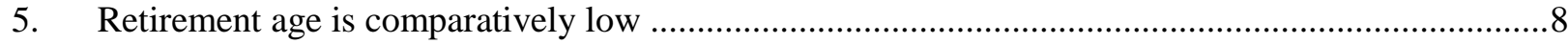

6. Total public pension expenditure is projected to grow strongly .....................................................

7. Projected public pension expenditure under the new and old pension systems .............................11

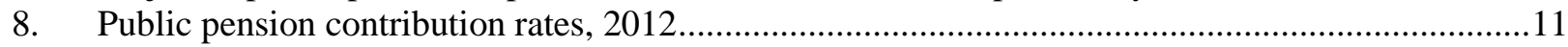

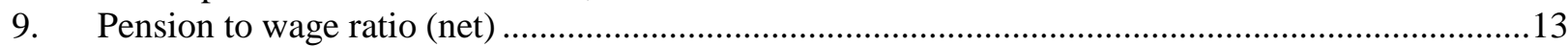

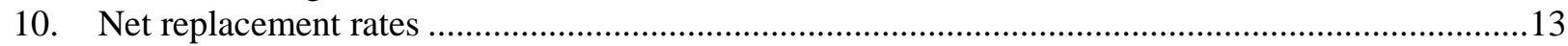

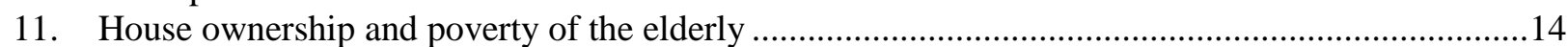

12. Importance of pension funds relative to the size of the economy, 2013 ........................................16

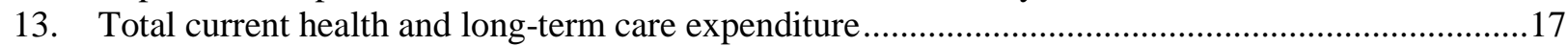

14. A big rise in health and long term care expenditures is projected in the future ..............................17

15. The share of general practitioners among all doctors is low ........................................................19

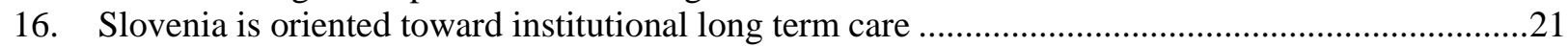

17. Life expectancy (LE) and healthy life years (HLY) at birth, by gender, 2012 ..........................21

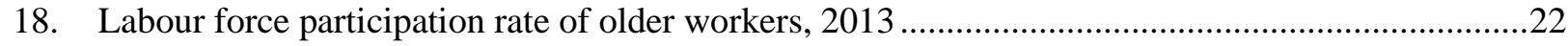

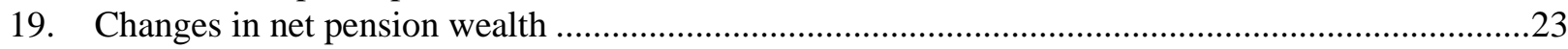

20. Protection of permanent workers against individual and collective dismissals, 2013 ....................24

21. Percentage of workers over 55 who report having been subject to age discrimination at work.......25

\section{Boxes}

Box 1. The pension reform of 2013 ...... 


\title{
THE ECONOMIC CONSEQUENCES OF AN AGEING POPULATION IN SLOVENIA
}

\author{
By Peter Walkenhorst and Urban Sila ${ }^{1}$
}

1. As in many other OECD countries, declining fertility rates and higher life expectancy are progressively changing the demographic structure and leading to a rapid ageing of the population in Slovenia. With fewer children entering the population and people living longer, older people are making up an increasing share of the total population. Also, migration to Slovenia is low and is not expected to be sufficient to counteract the ageing of the society. The old-age dependency ratio (the share of the population aged 65 and over relative to the population aged 15-64), is projected to rise from 25\% in 2013 to 55\% by 2060 (Figure 1, panel A). Moreover, the share of people aged over 80 in the total population will increase from $4 \%$ in 2010 to almost $11 \%$ in 2050 (Figure 1, panel B). This is faster than in many other OECD countries.

Figure 1. The population in Slovenia is ageing more rapidly than in most other OECD countries
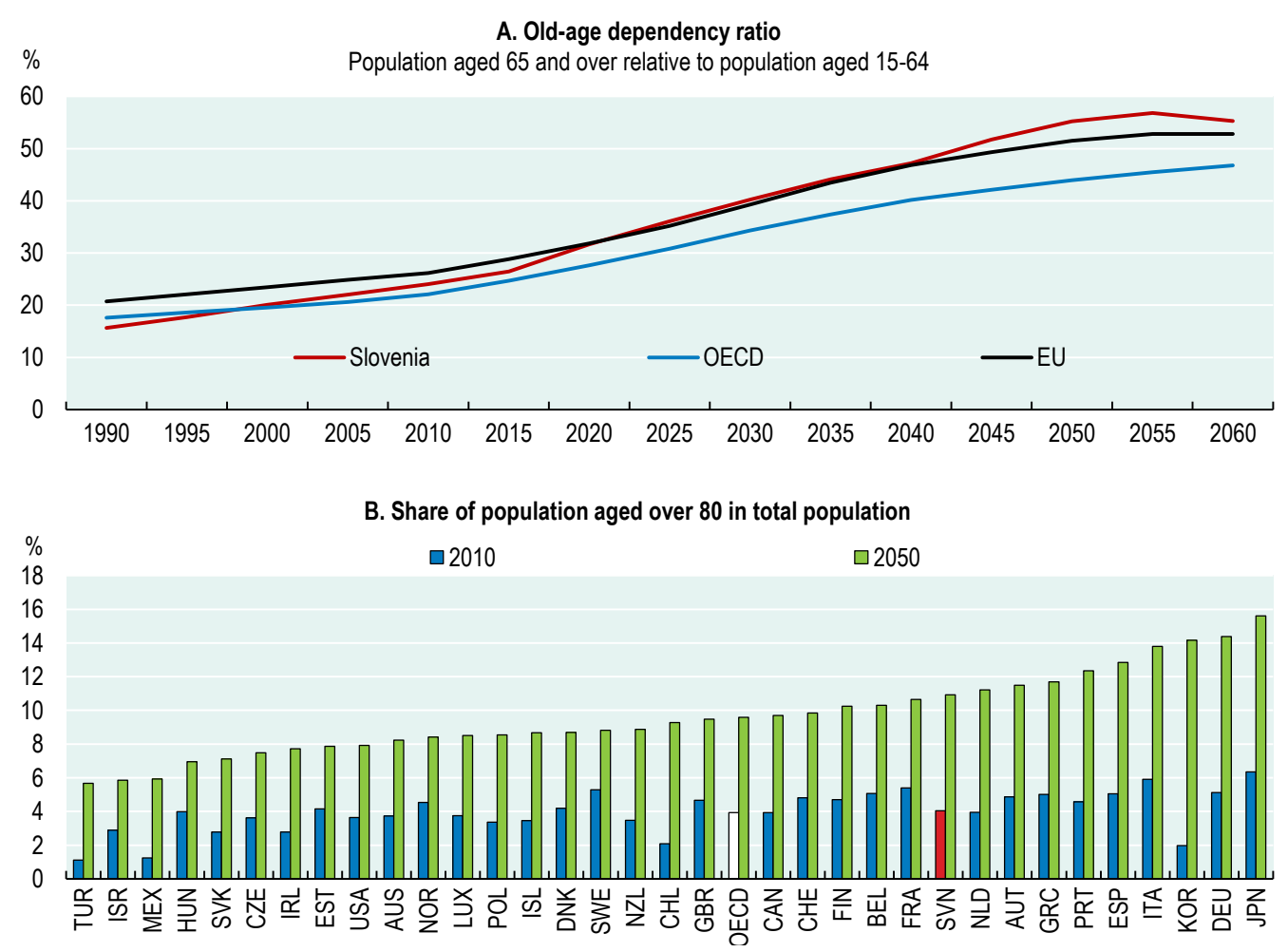

Source: UN, World Population Prospects: The 2012 Revision.

\footnotetext{
${ }^{1}$ Peter Walkenhorst is a former OECD Economist and worked as a consultant for Slovenia desk in the Economics Department. Urban Sila is an Economist working in the Economics Department, on the Slovenia desk. This paper is extracted from Chapter 2 of the 2015 OECD Economic Survey of Slovenia, published in May 2015 under the authority of the Economic and Development Review Committee (EDRC). The authors especially thank Piritta Sorsa, Nataša Jemec, Robert Ford, Álvaro Pereira, colleagues from other relevant OECD departments and Slovenian government officials for valuable comments on earlier drafts, Hermes Morgavi for statistical support and Anthony Bolton for editorial assistance.
} 
2. According to the Global AgeWatch Index, the well-being of older people in Slovenia shows a mixed picture (HelpAge International, 2014; Figure 2). The situation of the elderly compares favourably to many other OECD countries with respect to social connections, physical safety, civic freedom, and access to public transport, which constitute the "enabling environment" as well as "income security". In contrast, it scores below the OECD average for "health status", and is among the worst ranked with respect to "capability". The latter is the result of the low employment rate of older people, despite many older workers having completed secondary or tertiary education.

Figure 2. Well-being of people aged 60 years and more ${ }^{1}$

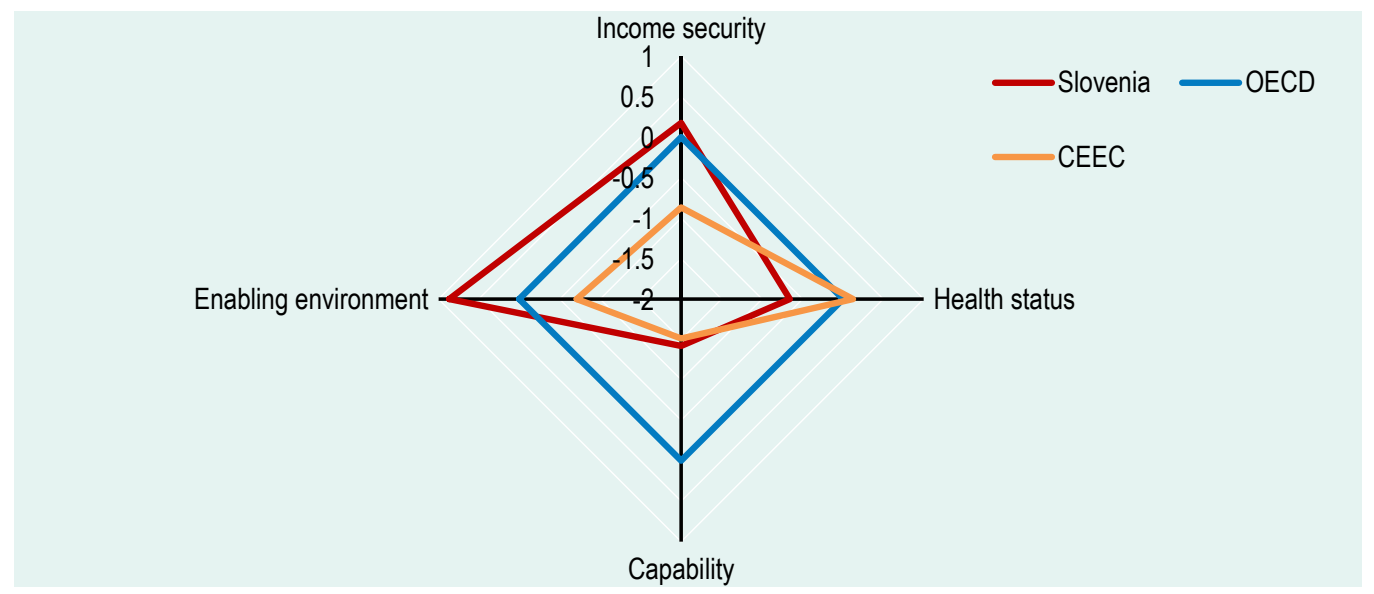

1. Each country's indicator is expressed as the difference with the OECD average and divided by the OECD standard deviation.

Source: HelpAge International (2014).

3. Providing older people with adequate pensions, high quality health care and gainful employment will become even more of a challenge in the coming decades. As a result of the demographic trends, Slovenia faces the prospect of a substantial increase in total age-related expenditure for pensions, as well as health and long-term care. Corresponding public expenditures are projected to rise by more than 3 percentage points by 2030 (OECD, 2014a; Figure 3) and more than 6 percentage points of GDP over the years 2013-60, compared with less than 2 percentage points for the European Union on average (European Commission, 2015). Hence, policy makers will need to act more strongly than in the past to rein in ageing-related outlays and to pursue efficiency-enhancing reforms of social support systems.

4. The remainder of this paper falls into four parts. The next section discusses the sustainability and adequacy of pensions in Slovenia in light of the reforms that were undertaken in 2013. The following section then turns to ageing-related challenges for the health and long-term care system and how the latter might need to evolve. Subsequently, the labour force participation of different segments within the population and labour market policies are assessed, with particular attention to older workers. A brief discussion on the benefits and opportunities of an ageing population concludes the paper. 
Figure 3. Age-related expenditures will exert significant pressure

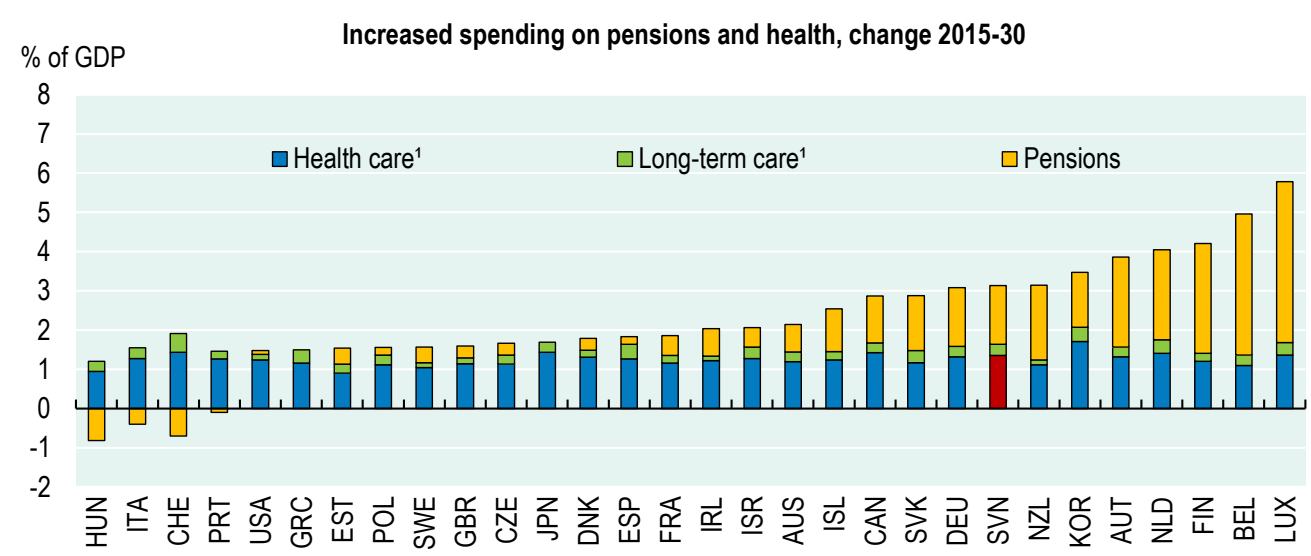

1. Based on "Cost-containment scenario", (Oliveira Martins and de la Maisonneuve, 2014). Where projections are not available over the period 2015-30, linear interpolation has been applied.

Source: Secretariat calculations based on Economic Outlook no 96 projections.

\section{Making the pension system sustainable requires further policy reform}

5. Public spending for old-age and survivor pensions is relatively high in Slovenia. In 2011, the respective expenditure amounted to $11.4 \%$ of GDP, compared with an average of $7.9 \%$ for the OECD (Figure 4). Several factors have contributed to the high pension expenditures, notably a relatively low average statutory and effective retirement age (Figure 5), short qualifying periods to receive a full pension, and longer pension drawing periods as life expectancy increased. Moreover, pension outlays in relation to GDP have risen by almost two percentage points since the global financial crisis in 2008, as year-on-year GDP growth has been negative, while the pensioner to active population ratio continued to increase.

\section{Figure 4. Public spending for old-age and survivor pensions is relatively high in Slovenia}

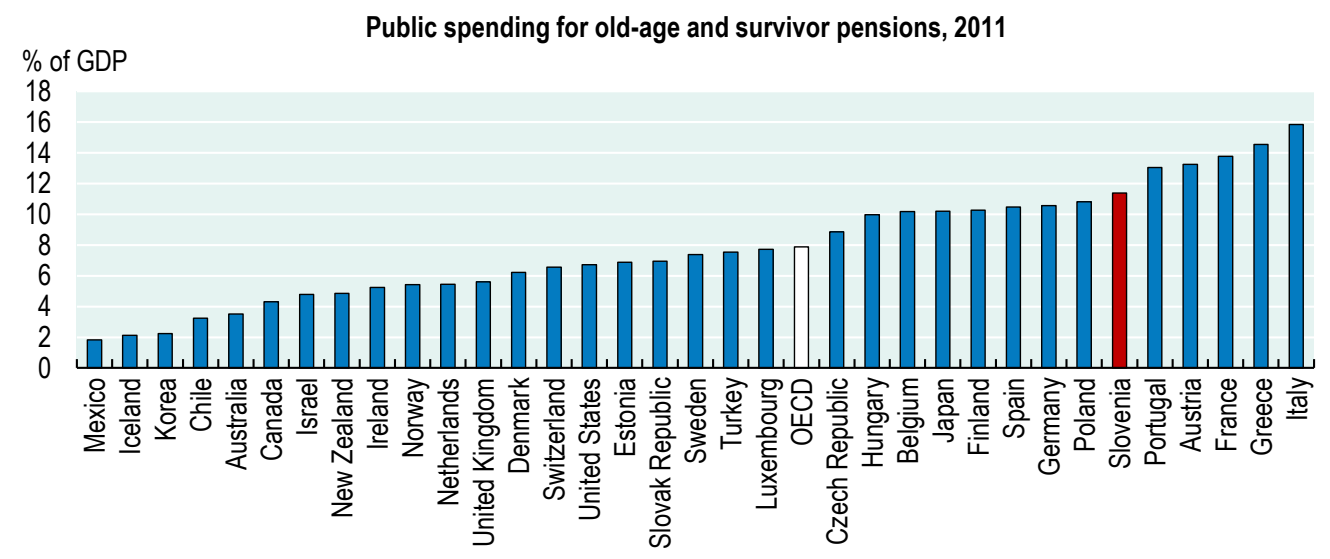

Source: OECD Social Protection and Well-being database. 
Figure 5. Retirement age is comparatively low
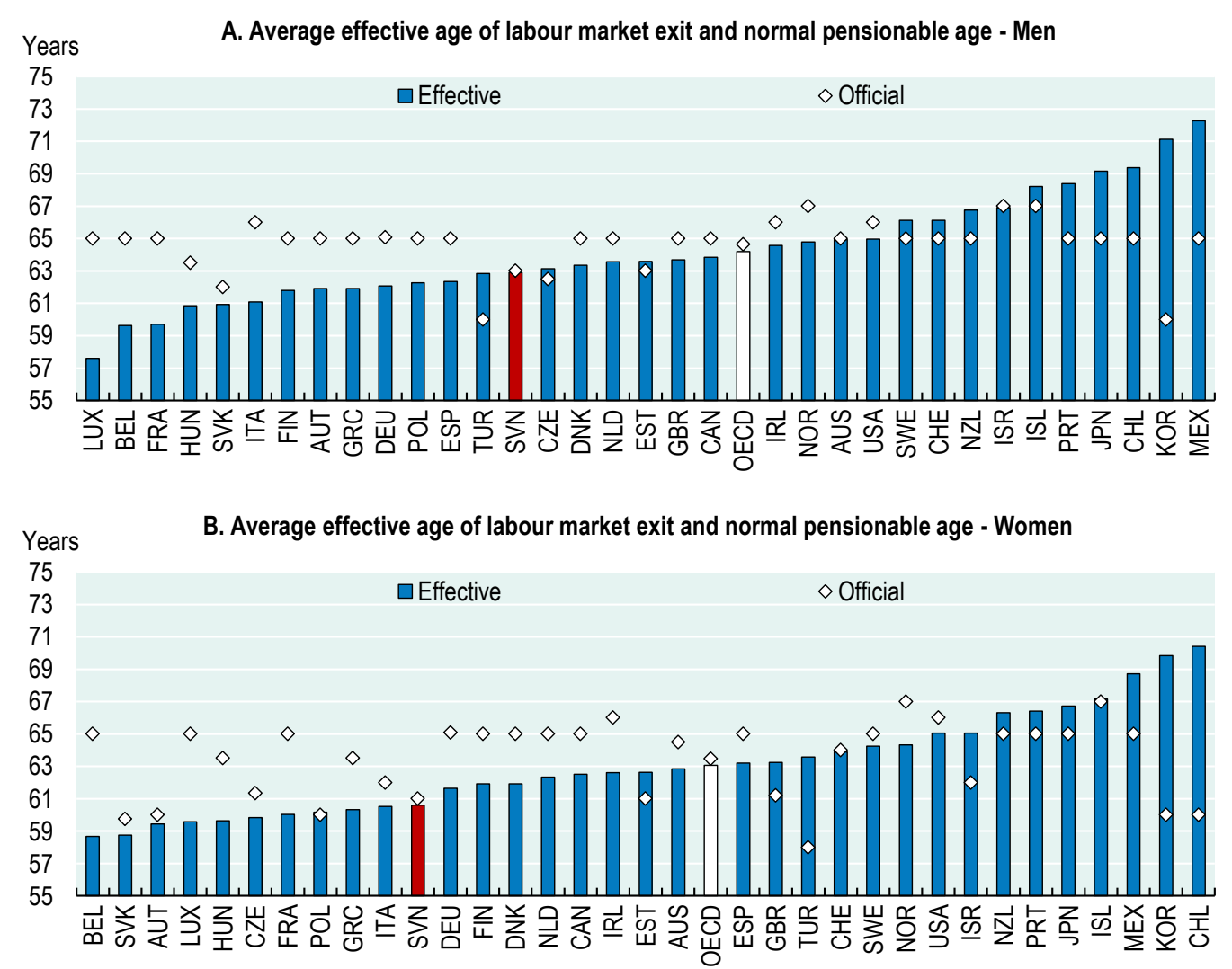

Note: Effective retirement age shown is for five year period 2007-12. Pensionable age is shown for 2012.

Source: OECD estimates based on the results of national labour force surveys and the European Union Labour Force Survey.

\section{Pressures on public spending will increase}

6. Going forward, pressure on the pension system will increase further as Slovenia's population ages rapidly. In fact, the baseline scenario of the European Commission's Economic Policy Committee projects a rise in total public pension expenditure of 3.5 percentage points of GDP for Slovenia between 2013 and 2060 (European Commission, 2015). The projection is more moderate than the OECD's pension outlook, which forecasts an increase in pension-related expenditures by 6 percentage points of GDP between 2015 and 2050 (OECD, 2014b). In any case, the increase is higher than in most other EU countries (Figure 6). While disability pension expenditure is expected to decrease and survivor pensions show only a moderate increase as a share of GDP, old-age pension outlays are driving the expenditure surge over time. Private pension expenditure remains of very modest importance. Slovenians have traditionally relied on the public pension system and the current policy regime does not provide strong incentives for private retirement savings. 
Figure 6. Total public pension expenditure is projected to grow strongly (2013-2060)

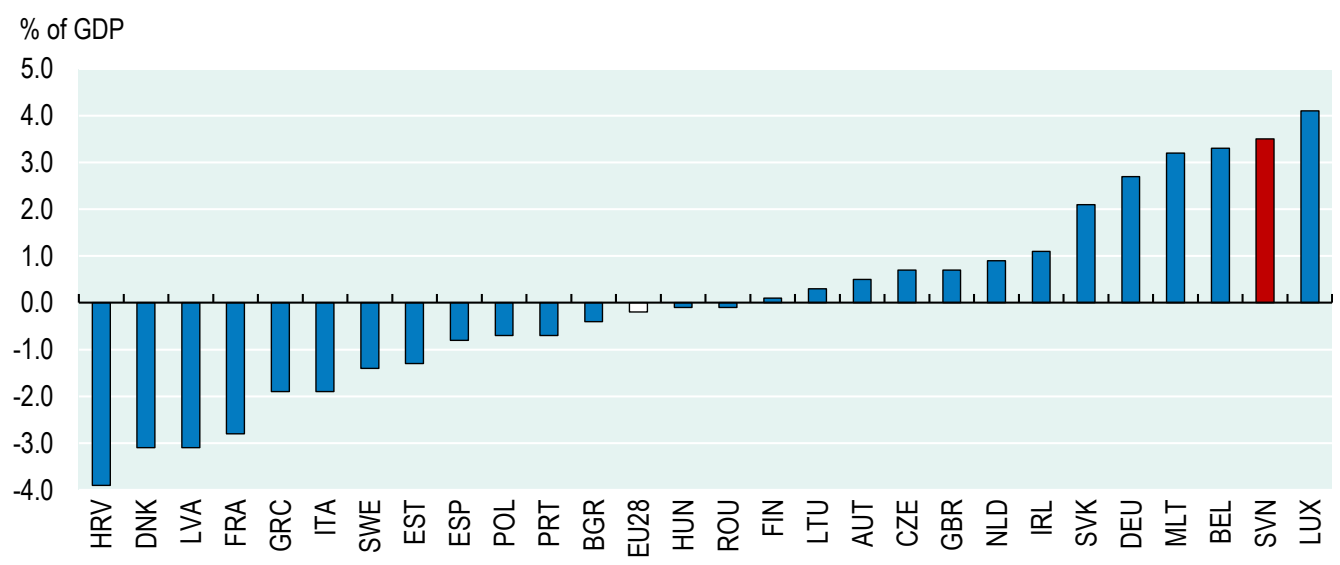

Source: European Commission, 2015 Ageing Report.

7. The Government of Slovenia is aware of the pending fiscal pressures and has started to pursue reforms to increase the sustainability of the pension system. In particular, new pension legislation was implemented in January 2013 that simplified the pay-as-you-go system, strengthened the link between contributions paid and pensions received and equalised the statutory retirement age for men and women at 65 years by 2020 (Box 2.1). These reforms are subject to transition periods from the previously existing system, but will be fully effective by 2022 .

8. Early results from the reforms are encouraging. The Ministry of Labour, Family, Social Affairs and Equal Opportunities published a first evaluation report in April 2014 that suggests that the new measures are helping to slow the inflow of new applicants into the pension system, increase the average retirement age and raise the share of retirees that have completed the full duration of the statutory working life (MDDSZ, 2014a). The reforms of 2013 will help to reduce and stabilize public pension expenditure as a share of GDP in the short to medium term. However, the achievements have to be seen in the context of a strong inflow into the pension system and related expenditure increases just before 2013 in anticipation of the reforms. Indeed, the additional pension expenditures in the run-up to the reforms and in the context of general fiscal consolidation might have crowded out other governmental spending.

9. In any case, projections undertaken at Slovenia's Institute of Economic Research show that the ongoing ageing of the population will soon lead to increases in public pension expenditure. While the reforms are expected to yield fiscal savings of up to $1.3 \%$ of GDP, the pre-reform expenditure to GDP ratio will be surpassed by 2020 and the ratio is projected to increase markedly thereafter (Figure 7). Hence further reforms will soon be needed to stabilise public pension expenditure. 


\section{Box 1. The pension reform of 2013}

The Slovenian pension system comprises two pillars. The first one is a mandatory pay-as-you-go defined benefit system, financed by contributions paid by employers $(15.5 \%$ of gross wages) and employees $(8.85 \%$ of gross wages) and direct transfers from the central government budget to cover any arising deficit $(4.1 \%$ of GDP in 2012). The second pillar consists of private, funded schemes, which are mandatory for two groups of employees - people working in hazardous or arduous occupations and public sector employees - and voluntary for others. About two-thirds of all employees are enrolled in second pillar programmes. Overall, though, the public pay-as-you-go system is by far the dominant source of income for pensioners. Annual payouts from the first pillar in 2012 amounted to more than twice as much as the value of total assets of the second pillar pension funds. All pensions are in principle subject to income tax, but pensioners benefit from a $13.5 \%$ allowance, and few then have incomes that exceed the income tax entry threshold (EUR 1150 per month). As a result, only about $5 \%$ of pensioners pay income tax.

On 4 December 2012, Slovenia's National Assembly passed a new Pension and Disability Insurance Act (ZPIZ-2), which came into force on 1 January 2013. The reform makes a number of parametric and systemic changes to the previous pension legislation (ZPIZ-1), mostly with the aim of putting the system's finances on a more sustainable basis. The main reform components are listed in the following.

The retirement age is being equalised for men and women and will be gradually raised to 65 years by 2020 . Under the previous system, men could retire at 63 and women at 61 . The minimum insurance period to qualify for an old-age pension has been reduced from 20 to 15 years of insurance contributions.

The possibility to lower the statutory retirement age due to child care, compulsory military service or early career start was maintained, but is available only under conditions that are more restrictive than under the previous system. Also, a person may retire at the age of 60 years already at a full pension, but only if he/she has 40 years of actual employment (or periods for which contributions were paid with regard to maternity, sick leave or unemployment). Under the previous system, the minimum age for receiving a full pension after 40 years of employment was 58 years.

Early retirement is now possible from the age of 60 (58 under the previous system), if a person has 40 years of pension insurance (including purchased periods, for example, for times spend for child care or in tertiary education), but is subject to a reduction in the pension by $0.3 \%$ per month of retirement before the statutory retirement age. Conversely, a bonus is provided for deferred retirement, with pensions increasing by $1 \%$ per three-month period of work beyond the statutory retirement age. The maximum pension bonus a person can obtain is limited to $12 \%$, which corresponds to three years of additional employment.

The calculation of the pension base takes into account the 24 consecutive years of insurance that are most favourable for the individual. Under ZPIZ-1, only the best 18 years of insurance were considered. A minimum pension assessment base is defined as $76.5 \%$ of the average net wage and a maximum pension base as four times the minimum base. The scheme pays $26 \%$ of the pension assessment base for men and $29 \%$ for women, once the minimum qualifying condition (15 years of contributions) has been met. Thereafter, the accrual rate is $1.25 \%$ per year, so that the net replacement rate after 40 years of contributions is $57.25 \%$ for men and $60.25 \%$ for women.

Moreover, the pension indexation method was changed, with pensions under ZPIZ-2 now being indexed to $60 \%$ of the increase in the average gross salary paid and to $40 \%$ of the average increase in the cost of living, while in the earlier system pensions were only linked to average gross salaries.

The new pension legislation also significantly broadened the scope of employers who can enrol their workforce in a supplementary, funded pension scheme (second pillar), while benefiting from tax relief.

Furthermore, a consultative personal register of compulsory insurance was established, with the aim of providing each insured person with easily accessible information on his/her notional and actually paid contributions. This will enable the insured person to verify whether the employer has actually paid contributions for his/her pension and disability insurance.

Source: Ministry of Finance, 2013; Stanovnik and Prevolnik Rupel, 2013. 
Figure 7. Projected public pension expenditure under the new and old pension systems

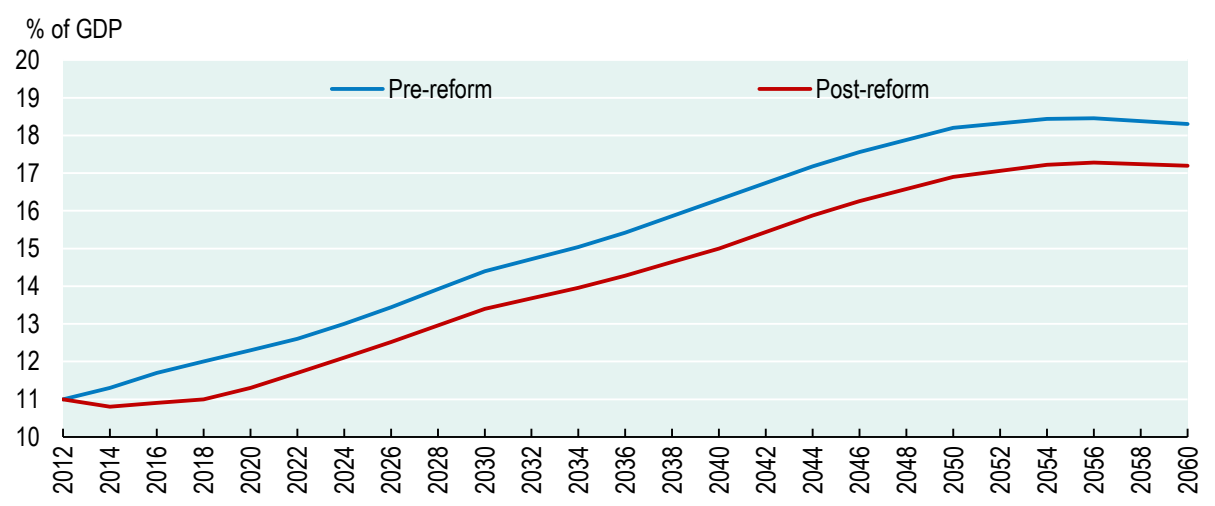

Note: Projections based on information on demographic developments as described in the European Commission's 2012 Ageing Report (European Commission, 2012a).

Source: Majcen et al., 2012.

\section{Additional reforms to achieve sustainability}

10. The funding gap could in principle be closed by measures either on the revenue or the expenditure side, or a combination thereof. However, the potential to increase revenues for the public pension system by increasing contribution rates seems limited. The average labour tax wedge in Slovenia for a single person earning average wage stands at $42.3 \%$, substantially above the OECD average of $35.9 \%$, and is even higher for high earners (OECD Taxing Wages database). Similarly, the total public pension contribution rate of $24.4 \%$ of gross earnings puts Slovenia towards the upper end of the OECD scale (Figure 8). Increasing the pension contribution rates further in this context would put an additional burden on the active population and risk adverse consequences for employment, work incentives and competitiveness. Some countries have started to raise revenue to finance ageing-related expenditures by levying contributions on capital income at the personal level - as is the case in France - or use indirect energy tax revenues - as in Germany. However, given the already high top personal income tax rates in Slovenia, raising sources from capital income could come perhaps as a substitute for lowering contributions on labour incomes. The potential to increase revenues is therefore limited.

Figure 8. Public pension contribution rates, 2012

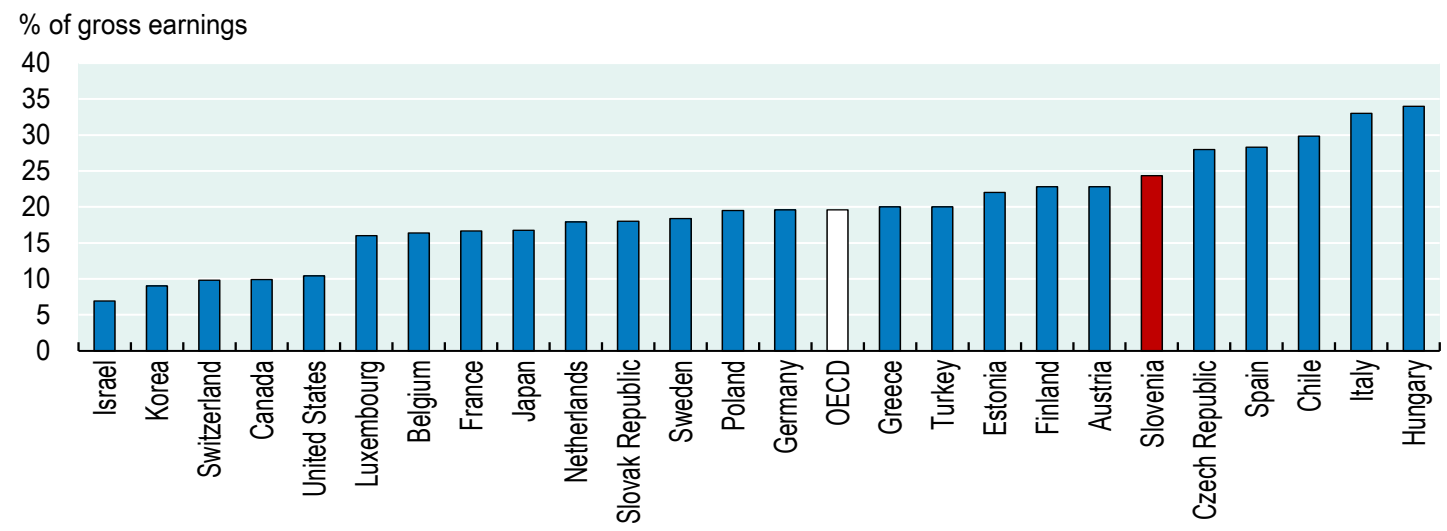

Source: OECD Pensions at a Glance 2013. 
11. Renewed reform efforts should focus on further altering many of the parameters that were adjusted by the 2013 reform. In particular, the statutory retirement age should be gradually increased beyond 65 years to better balance contributing and pension receiving periods as life expectancy increases. Indeed, about half of OECD countries have elements in their mandatory retirement-income provision that provide an automatic link between pensions and a change in life expectancy (OECD, 2011a). The most obvious form of such links is thereby to increase the pensionable age as people live longer. This indexing of the statutory retirement age to life expectancy is, for example, being introduced into the pension systems of Denmark, Greece, and Italy. Automatic adjustment means that governments no longer encounter gaps in pension financing when projections of life-expectancy change. Also, controversial political discussions on cutting future benefits could be avoided if increased life expectancy provides a direct and logical justification for the policy change.

12. Another avenue to stabilise pension expenditure would be to shorten the gap between statutory and early retirement ages and to better reward longer service time. Retirement choices are driven by diverse determinants related to an individual's health status, professional position, household situation, as well as socio-cultural and institutional factors (Van Erp et al., 2013), but financial aspects also play an important role. The 2013 pension reform already tightened the requirements for early retirement to some extent, but further provisions to extend the service period required to obtain a full pension and stronger incentives for older workers to remain in the labour force would help make the pension finances more sustainable. For example, limiting the entry age for early retirement to a maximum of two years prior to the statutory retirement age and imposing larger pension deductions for early retirement could make a significant contribution to the sustainability of the system (IMF, 2015).

13. Moreover, adjustments in the pension base have a role to play. The 2013 pension reform increased the number of years on which pensions are based from the best 18 to the best 24 . Once the new pension reform is fully phased-in by 2020 , a male pensioner with 40 years of contributions is expected to obtain benefits equal to $57 \%$ of the pension rating base, and a female pensioner $60 \%$. This represents a decrease of up to 0.38 percentages points (by 2060) compared to the earlier system (Ministry of Finance, 2013). However, the 2013 reforms stopped short of adopting a system based on lifetime contributions, so that the pension base would be based on average wages rather than earnings during a period of highest wages. Moving to such an average-earnings system will tend to decrease the pension base and - unless adjustments to the accrual coefficients are made - the benefits paid out. At the same time, however, the shift to a lifetime contribution system will have distributional consequences with individuals with steep earnings growth or volatile career paths facing strong declines in their pension benefits (Disney and Whitehouse, 1999). These distributional impacts will have to be considered and potentially addressed through complementary measures.

14. Further, placing a greater weight on prices, rather than wages, in the indexation of pensions will lower costs over time. The 2013 pension reform introduced a mixed indexation based on $60 \%$ gross wages and $40 \%$ consumer prices. Putting additional weight on prices will make it possible to maintain the purchasing power of pensioners, while avoiding that labour productivity gains translate into higher pension expenditures. Some OECD countries, such as France, Japan, Spain, United Kingdom or United States, are only taking price inflation into account when indexing pensions. Meanwhile, Slovenia has taken ad hoc policy measures to contain the increase of pension outlays due to indexation as part of the government's austerity programme. Since 2010, pension indexation has been partially or completely frozen. It was reduced, respectively, to half and a quarter of nominal wage growth in 2010 and 2011, and completely frozen in 2012. In 2013, a 0.1\% increase in pensions was accorded, while in 2014/15 the indexation is again fully suspended. 
15. It is important to keep in mind, however, that containing pension costs by cutting replacement rates has implications for pension adequacy. The pension to wage ratio (net of social security contributions and personal income taxes) in Slovenia has fallen from $73 \%$ in 2001 to 62\% in 2012 (Figure 9). The drop has been particularly pronounced since 2010 , when pension indexation was partially suspended. While the replacement rates for low income workers in Slovenia continue to be in line with the OECD average (Figure 10), the decrease in the level of average pensions over time might raise concerns about the well-being of the lowest income groups and the effective protection of pensioners against old-age poverty.

Figure 9. Pension to wage ratio (net)

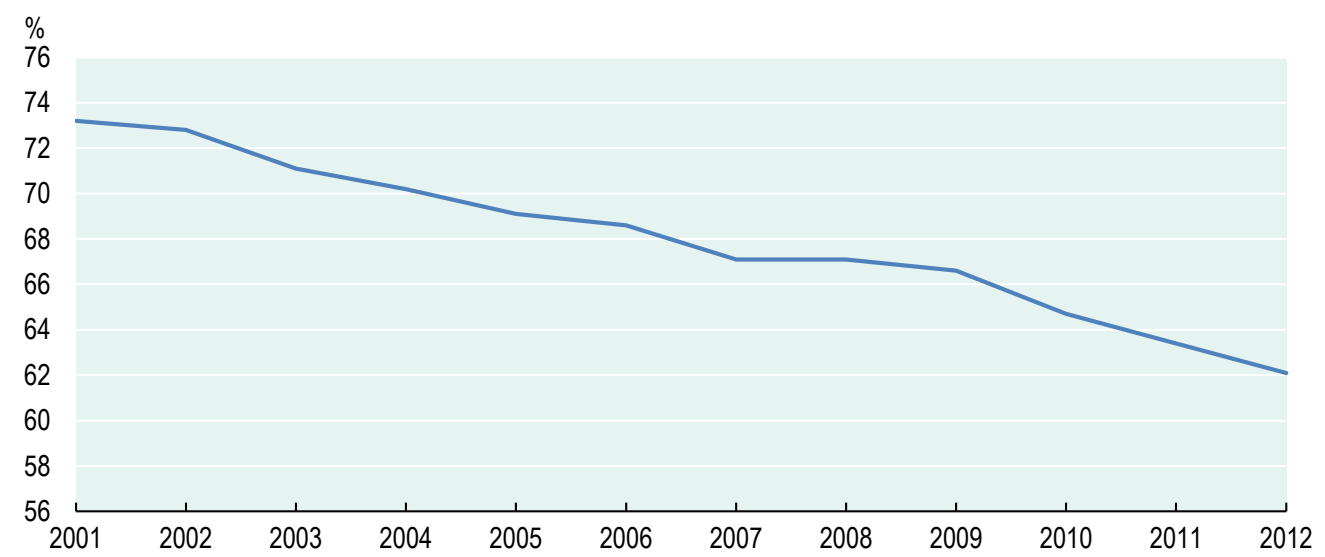

Source: Stanovnik and Prevolnik Rupel, 2013.

Figure 10. Net replacement rates

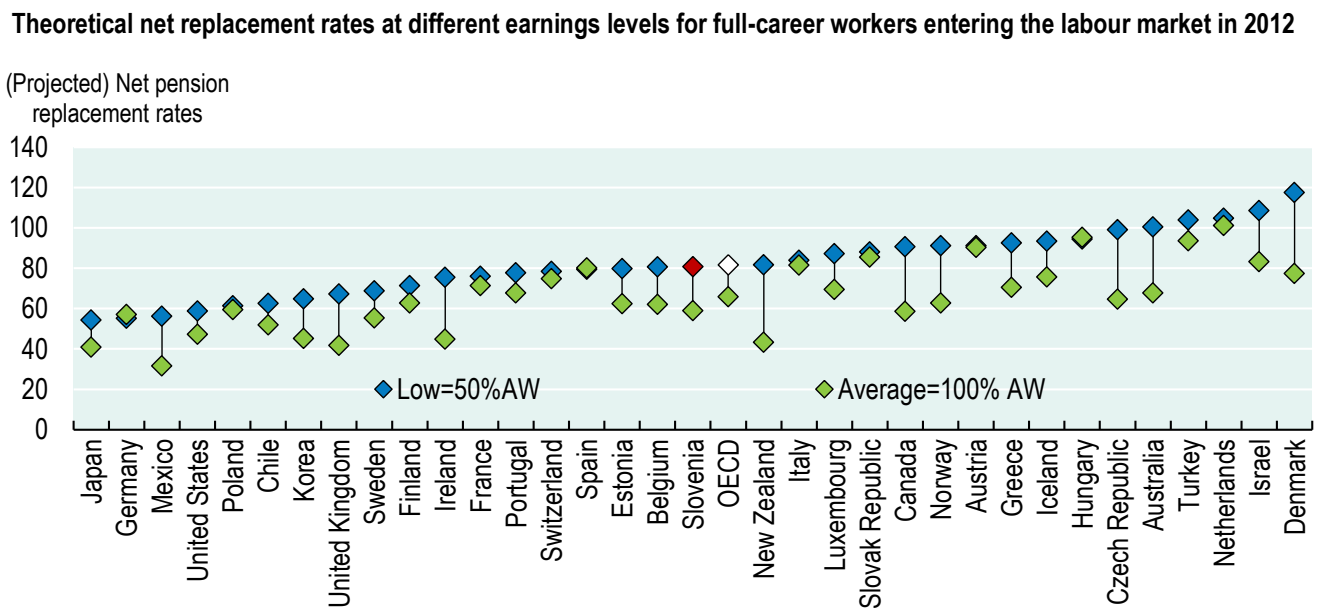

Note: "Average" and "Low" earnings levels refer to $100 \%$ average wage and $50 \%$ of the average wage respectively.

Source: OECD Pensions at a Glance 2013.

16. The relative income poverty rate of the elderly, defined as less than one-half the median income, amounts to $17 \%$ and is thus substantially higher than corresponding figures for other age groups or the OECD average at $12 \%(\mathrm{OECD}, 2014 \mathrm{c})$. Old-age poverty in Slovenia is not evenly distributed, but affects in particular women over65, who are twice as likely as men to have low pension incomes (Stanovnik and 
Prevolnik Rupel, 2013). This gender gap is the result of shorter pension contribution periods by women, lower salaries earned and pension contributions made, and a higher likelihood to live in single households due to longer female life expectancy. The 2013 pension reform aligned the retirement ages and minimum contribution periods of men and women, but the effects will only be felt in the longer term, and the other two determinants of the gender gap will remain.

17. The level of pension benefits provided by the public pension system is generally the prime determinant of retirement-income adequacy, but there are other resources that provide incomes or benefits to retirees. In particular, many retirees in Slovenia own their homes. In fact, home ownership at $84 \%$ among individuals over 65 is among the highest in the OECD (Figure 11, panel A). Unlike people of working age, older homeowners have generally paid-off their mortgages and thus fully benefit from not having to pay rent (while, however, having to assume home maintenance costs and property taxes). If this benefit is taken into account as imputed rent, the economic situation of pensioners in Slovenia improves markedly. The poverty rate falls by $60 \%$ or more compared to the assessment without imputed rent (Figure 11, panel B). The findings are shown based on poverty rates with fixed and floating poverty lines. When the line is fixed, poverty is computed by comparing the incomes, augmented by net imputed rents, with the original poverty threshold calculated without imputed rent. With a floating line, poverty is computed with reference to a new income threshold that also includes the (net) imputed rent (OECD, 2013a).

Figure 11. House ownership and poverty of the elderly
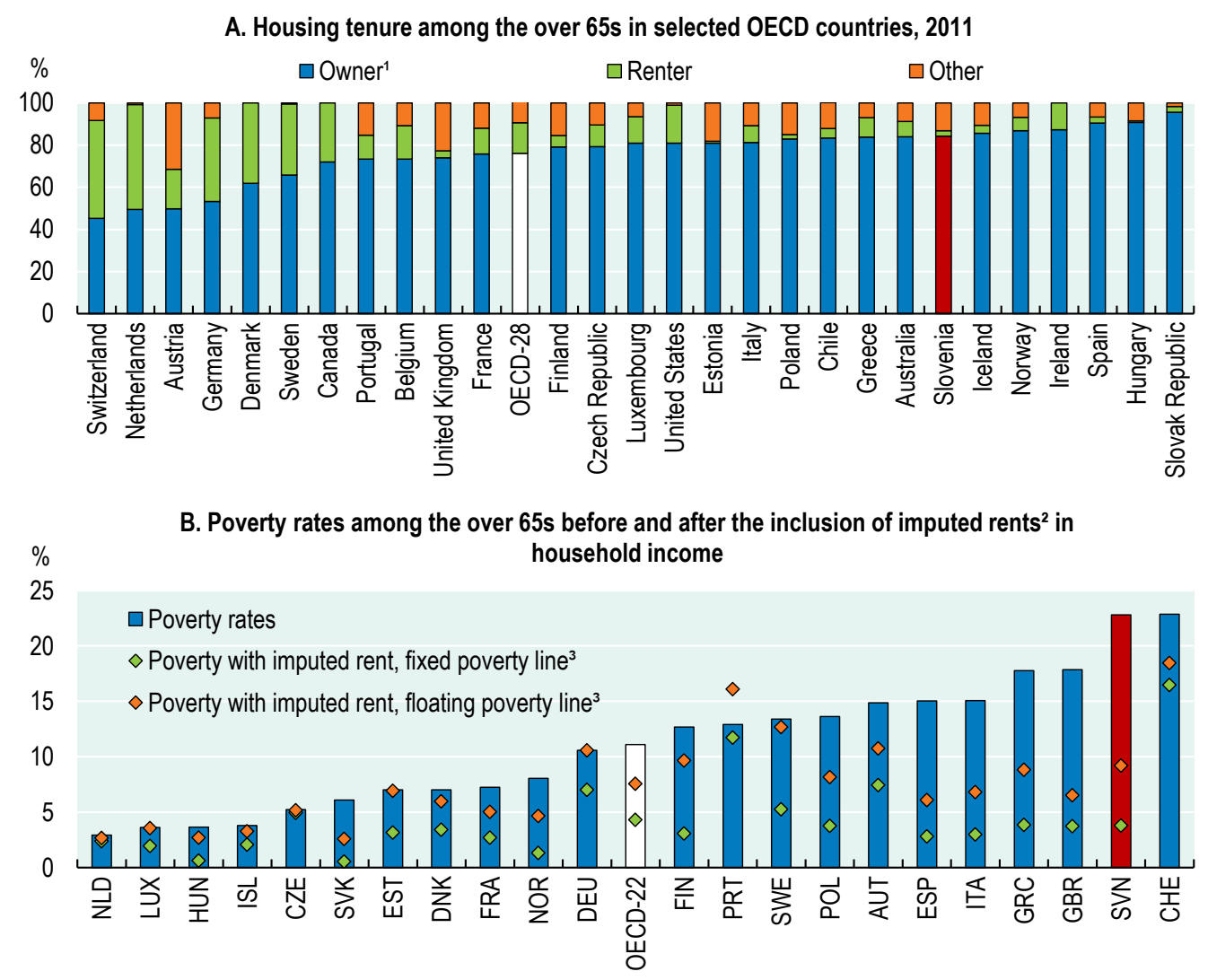

1. The category "owner" includes both outright owners and owners who are still repaying a mortgage.

2. The income stream which owners could draw from their homes and "save" by living in them is commonly termed "imputed rent".

3. When the line is fixed, poverty is computed by comparing the incomes, augmented by net imputed rents, with the original poverty threshold calculated without imputed rent. With a floating line, poverty is computed with reference to a new income threshold that also includes the net imputed rent.

Source: Pensions at a Glance 2013. 
18. A dwelling is, of course, also an asset that could be sold and the proceeds could be used to supplement the pensioners' income. Similarly, financial savings and capital income can also complement public pensions. In Slovenia, the financial assets held by pensioners are relatively modest, though, and consist to a large extent of bank deposits (OECD, 2013a). In particular, income from private funded pensions and life insurance policies - sometimes referred to as the third pension pillar - are not enhancing pensioners' income in any substantial way.

\section{Private pensions are of minor importance}

19. Slovenia has a second pillar in its old-age support system - supplementary pensions, which are a defined contribution plan. There are two mandatory supplementary pension schemes, which, respectively, cover employees in the public sector and workers performing arduous or hazardous tasks. These two groups are enrolled in two closed pension funds (SODPZ and ZVPSJU), which are managed by a state-owned company (Kapitalska Družba). In addition, several voluntary schemes exist that are organized by particular employers. Pension contributions from both the employer and the employee benefit from tax relief up to $5.8 \%$ of the gross wage of the employee. There is a minimum guaranteed rate of return on the paid in net premium, which should not be lower than $40 \%$ of the average annual interest on government securities with the maturity exceeding one year. The minimum return is guaranteed by the pension scheme provider over the whole period of the active participation in the supplementary pension scheme (OECD, 2011b).

20. Partly due to their relatively recent establishment, none of these funded pension schemes have been able to accumulate sufficient assets to provide adherents with viable supplementary pensions. Also, the public employee fund has suffered from early withdrawals, as participants took out lump sum payments after completing the minimum ten year contribution period, instead of continuing to save for old-age pensions. The poor performance of the private pension funds during the global financial crisis and the hardship many contributors experienced during that period motivated many of these withdrawal decisions (Ministry of Finance, 2013).

21. Moreover, the occupational pension fund had to assume unfunded entitlements when it was created, which has led to high contribution rates (10.6\% of gross wages, paid by the employer) (Stanovnik and Prevolnik Rupel, 2013). Also, participation is determined by an outdated list of hazardous occupations, which does not provide employers with incentives to improve working conditions. For example, few printers are nowadays exposed to lead, so that their classification as a hazardous occupation is questionable. These shortcomings were not addressed in the 2013 pension reform. Hence, in order to improve the functioning of the occupational pension fund, the authorities should revise the list of activities that are considered arduous or hazardous, and determine the contribution rates to the occupational pension fund in accordance with actuarial principles.

22. Overall, the second pillar is not expected to yield substantial supplementary income for pensioners. In addition, assets in private pension funds are small and substantially below the OECD average (Figure 12). The European Commission forecasts the contribution from funded pensions in Slovenia to gradually grow over time, but merely reach $0.3 \%$ of GDP by 2060 (European Commission, 2012a). In this context, the authorities might want to provide incentives to strengthen the role of voluntary private pensions in order to complement the incomes of the elderly.

23. Slovenia no longer provides a minimum pension, but it offers means-tested minimum income support to (elderly) individuals with very low incomes. In January 2012, new social legislation took effect that modified the right to minimum pension support and transferred it from the pension insurance to a social assistance scheme, which is welcome. The maximum amount of supplementary income support for a single eligible person without any other sources of income was EUR 449.80 in 2012, and for a household 
with two eligible individuals it amounted to EUR 673.40 (Ministry of Labour, Family, Social Affairs, and Equal Opportunities, 2013). For comparison, the average net earnings of a single person in Slovenia amounted to EUR 976 in 2012 (Eurostat, Labour market database).

Figure 12. Importance of pension funds relative to the size of the economy, 2013

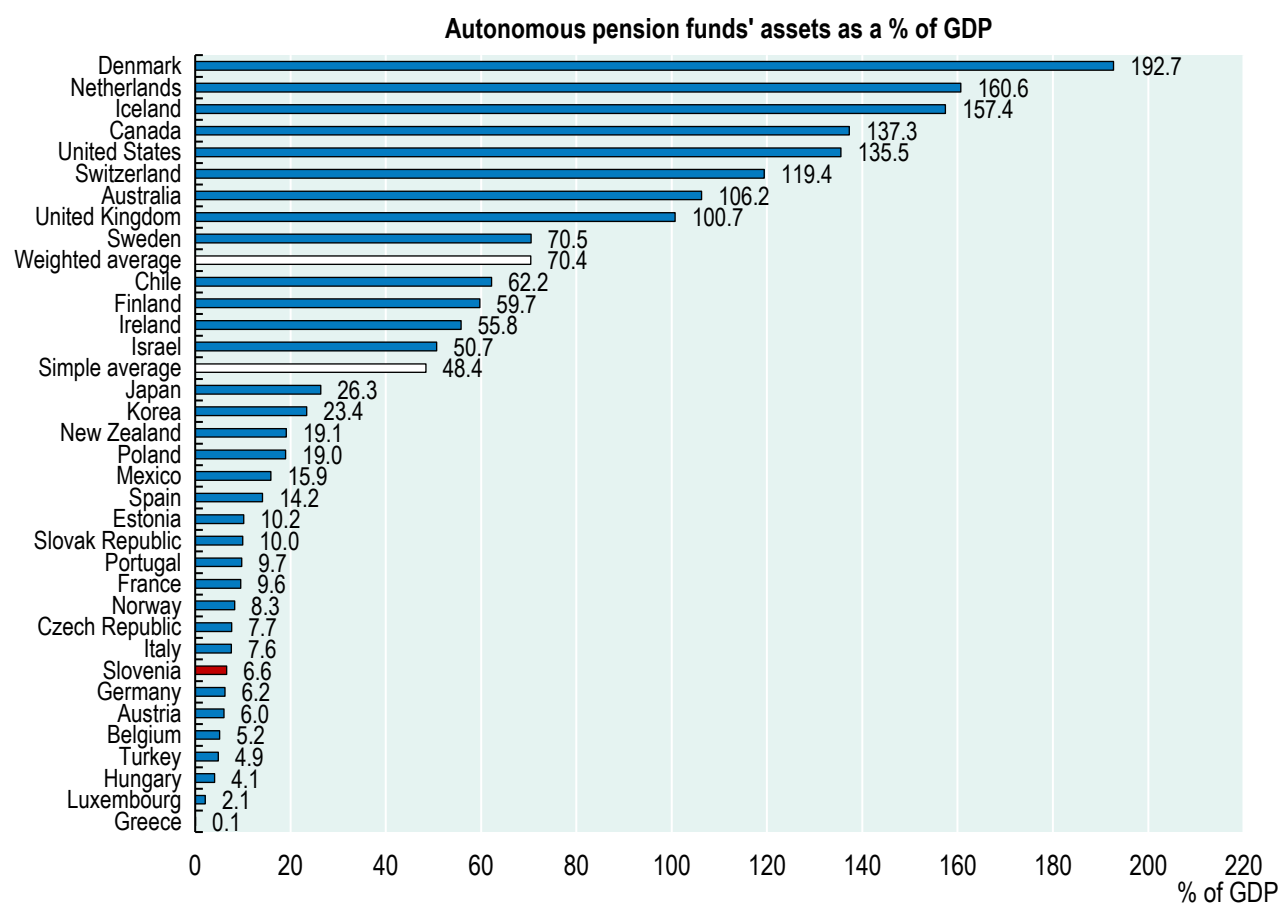

Source: OECD Funded Pensions Indicators; and Bank of Japan.

\section{The health and long-term care systems are awaiting reform}

24. An ageing population also has substantial implications for health care provision and related costs. Typical health expenditure profiles show average outlays as being relatively high for young children, subsequently they decrease and nudge up only gradually for most of the prime-age period, before they start to increase rapidly in older age (De la Maisonneuve and Oliveira Martins, 2013). Hence, a rising proportion of older people is placing upward pressure on overall health care spending, although other factors, such as income growth and advances in medical technology, also play a major role.

25. There is growing evidence that with suitable policies and programs people can stay healthy and independent well into old age and can continue to make contributions to their communities and families. Yet, the potential for an active, healthy old age is often compromised by dementia, whose prevalence rises sharply with age. An estimated 25-30 percent of people aged 85 or older world-wide suffer from the syndrome (WHO, 2011). Unless new strategies for prevention and management are discovered and applied, the rising number of people with dementia is expected to place growing demands on health care systems.

26. Moreover, many of the very old lose their ability to live independently because of physical malfunctioning that leads to limited mobility or frailty. Many require some form of permanent assistance for the most basic activities of daily living, creating a heavy economic and social burden on families and the wider community. Reducing severe disability from disease and health conditions is thus one central element for containing health care costs in an ageing society (WHO, 2011). The longer people can live independently, care for themselves and remain mobile, the lower are the costs of long-term care. 
27. Total expenditure on health and long-term care in Slovenia amounted to $9.2 \%$ of GDP in 2012 and remains in line with the OECD average (Figure 13), but higher than in many countries with a similar level of GDP per capita. In 2013, the share of health expenditure in GDP dropped to $9.1 \%$ and was estimated at $9.0 \%$ in 2014. Under the European Commission's reference scenario, health care expenditure is expected to increase by 1.1 percentage points of GDP between 2013 and 2060, while outlays for longterm care would be 1.5 percentage points of GDP higher by 2060 (European Commission, 2015). The total increase in health and long-term care expenditures would, thus, amount to 2.7 percentage points of GDP by 2060 (Figure 14). Projections by the OECD predict an even stronger surge in health and long-term care expenditures (De la Maisonneuve and Oliveira Martins, 2013). Under a cost containment scenario, total health costs in Slovenia would increase by 3.6 percentage points of GDP until 2060, while in the cost pressure scenario, the expenditure hike would amount to no less than 8.2 percentage points of GDP. The "cost pressure scenario" assumes that no policy action is undertaken to curb rises in expenditure, whereas the "cost-containment scenario" assumes some policy action to rein in these expenditure pressures, such as measures to limit the growth of relative health prices.

Figure 13. Total current health and long-term care expenditure

2012 or latest data available

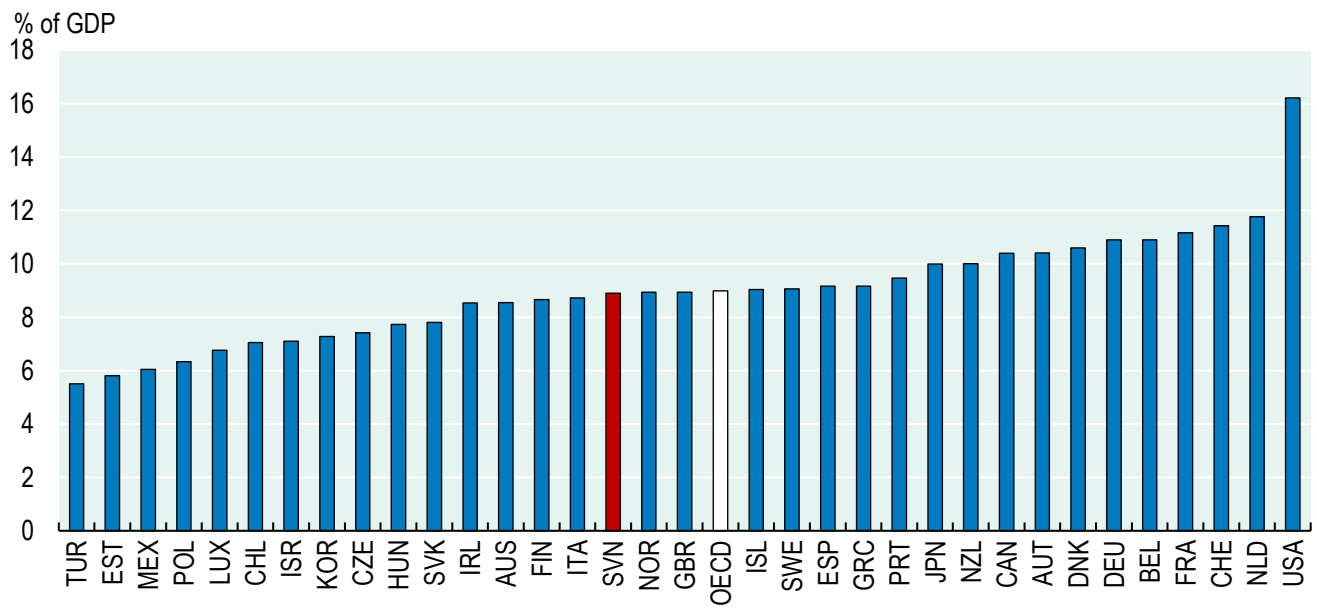

Source: OECD Health database.

Figure 14. A big rise in health and long term care expenditures is projected in the future

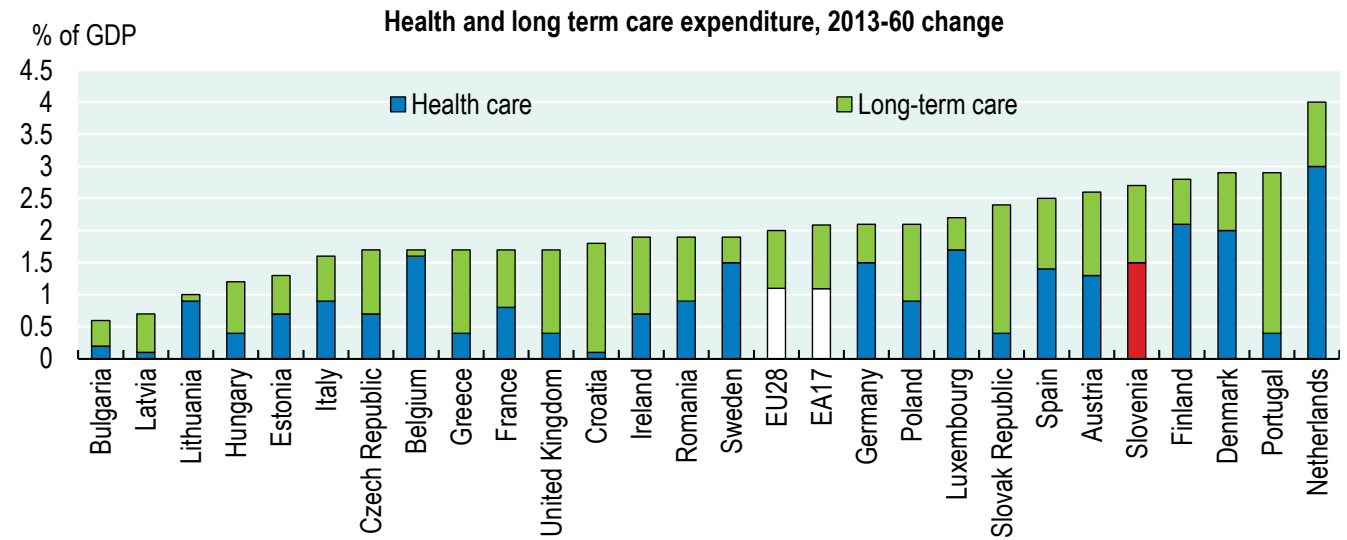

Source: European Commission 2015 Ageing Report. 
28. The current health care system in Slovenia has been in place since 1992. Health and long-term care are financed through compulsory health insurance, which is administered by the Health Insurance Institute of Slovenia (ZZZS), and through voluntary complementary insurance, which can be obtained from three private insurance companies (Vzajemna, Adriatic, and Triglav). A risk-equalisation scheme among the three insurance companies was introduced in 2005 based on open enrolment and equal risk premiums in order to avoid discrimination according to age, gender and health status. The compulsory insurance gives the insured access to free coverage of basic treatments within the public provider network against a fixed share of their gross wages (7.09\% paid by employers plus $6.36 \%$ paid by employees), pensions $(5.65 \%)$ or incomes. The voluntary complementary insurance, which individuals can purchase against a flat fee (at around EUR 27 per month in 2012), covers most or all expenses that are not fully reimbursed by the compulsory insurance. In addition, individuals can buy private supplementary insurance that provides access to additional medical services (or decide to pay for such services out-of-pocket). The coverage of compulsory health insurance is virtually universal, while $95 \%$ of the population buy voluntary complementary insurance.

29. Rising costs and the economic downturn following the global financial crisis of 2008 have resulted in the emergence of severe financial constraints for the Health Insurance Institute of Slovenia. These have been tackled through short-term austerity measures, such as rate cuts for health care service provision, lowering of reimbursement rates from the compulsory insurance system, and augmentations in contribution rates for the voluntary complementary insurance. As a consequence, the accessibility to health care services has decreased, both in terms of lower affordability and increased waiting times. In particular, the share of private health care funding gradually increased from $26 \%$ of total expenses in 2008 to $28 \%$ in 2013 (Stanovnik and Prevolnik Rupel, 2013), and the number of patients on waiting lists increased from 39000 in 2011 (across 52 services monitored) to 76000 in 2014 (47 services monitored) (Ministry of Health, 2015).

30. Some of the cost drivers seem endemic to the system. Despite recent growth in the number of general practitioners, their share among all doctors is still low (Figure 15) and the allocation of resources is skewed to more costly specialist care. A third of overall healthcare spending is on inpatient care, and more could be done to further develop ambulatory care (OECD, 2013b). The Commission for the Prevention of Corruption reports that the public health system is inefficient in its public procurement and susceptible to conflicts of interest. The decentralised Slovenian health providers pay significantly higher prices for the equipment and materials in comparison to their counterparts in many EU countries (CPC, 2014). Also, research findings using the OECD's Data Envelope Analysis methodology suggest that, overall, the Slovenian health care system achieved only a $52 \%$ efficiency score relative to frontier countries, such as Chile, Israel, Italy and Japan (IMF, 2015).

31. In this context, the Insurance Institute of Slovenia has undertaken several cost-cutting initiatives, notably the classification of drugs by categories, negotiations with suppliers to reduce the prices of medicines, expansions of the lists of mutually interchangeable drugs, the determination of the highest recognized prices/costs of medicines, and the introduction of new therapeutic groups. Moreover, to increase efficiency and transparency, the Ministry of Health has started to centralise the procedures for purchasing of drugs and pharmaceutical products, and this practice is planned to be extended to medical equipment. 
Figure 15. The share of general practitioners among all doctors is low

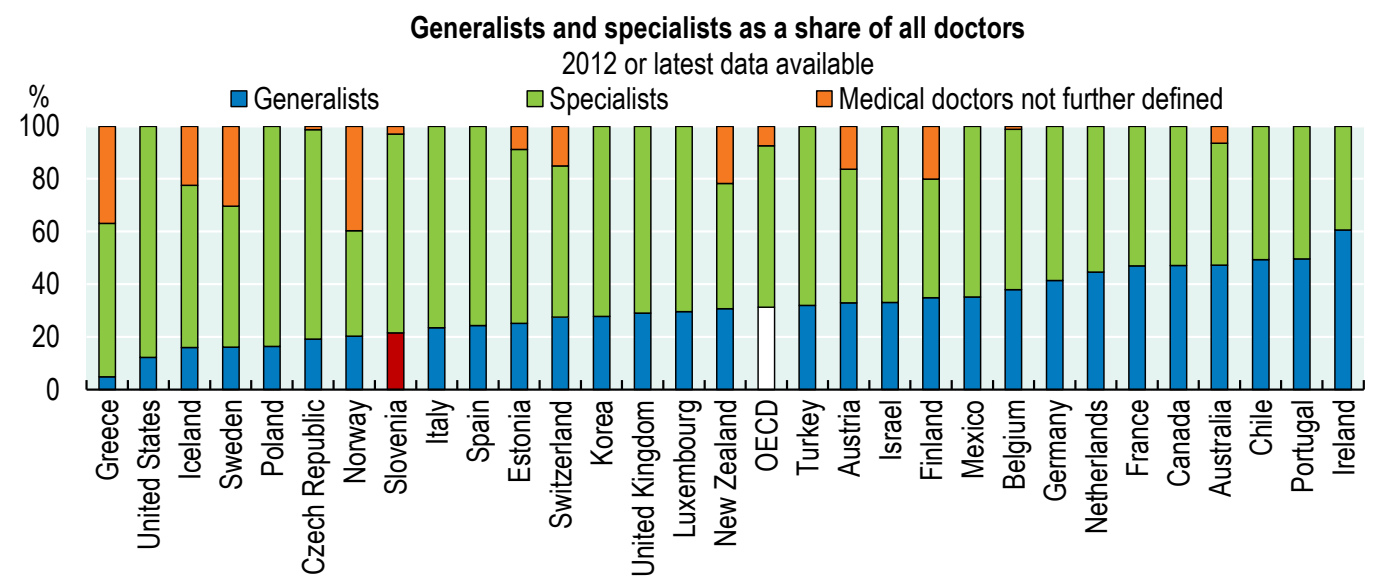

Source: OECD Health Care Resources database.

32. The government is undertaking a comprehensive review of expenditure at state and local government levels, direct and indirect budget users and municipality-owned providers of facilities and services, scheduled for the first half of 2015. The aim of the assessment is to evaluate the potential for improving the cost-effectiveness and quality of service delivery and to identify institutional reforms and marked-based mechanisms that could generate synergies and cost savings. The findings of the review will serve as inputs into a comprehensive health sector reform that the government intends to launch towards the end of 2015.

33. The health insurance system in Slovenia has a number of redistribution elements. There is no upper contribution threshold for the compulsory health insurance, so that high income employees pay much more into the insurance pool than would be actuarially needed to cover their health risks. Pensioners face a lower contribution rate than employees and despite higher contributions from the self-employed since the beginning of 2014, they contribute less than comparable wage earners. Moreover, the voluntary complementary insurance consists of a flat fee, which represents a heavy burden on low income individuals. Hence, contribution rates of different groups within society might need to be reviewed in order to reduce or avoid distortions in the system.

34. The Slovenian government already addressed one distortive exemption from social contributions when it reformed the treatment of student work in early 2015. In Slovenia, many young high school or university graduates used to have problems in entering the labour force. For entry-level positions, companies preferred to hire student workers on temporary contracts, as they provided flexibility and did not require contributions to the social security system. This practice led to increased unemployment among young graduates and extended study periods (OECD, 2013b). From February 2015, students will have to make a $15.15 \%$ contribution to the pension system, while employers have to pay $8.85 \%$ in pension contributions and $6.36 \%$ in healthcare insurance contributions. Also, the minimum wage for student workers was fixed at EUR 4.50 per hour, which is $10 \%$ below the regular minimum wage. 
35. Another element in need of reform is the voluntary complementary health insurance. It currently covers the full remaining part of the costs of most treatments that are not fully reimbursed by the compulsory health insurance. Hence, neither medical practitioners nor patients have an incentive to ensure that the treatments and drugs prescribed are effective and necessary. In this context, the authorities should reform the system to limit insurance cover to a basket of proven and effective drugs and services and let patients pay for any additional treatments they desire out-of-pocket or through private insurance.

\section{Long-term care deserves the attention of policy makers}

36. The health care system reform will also provide an occasion to put the financing and delivery of long-term care (LTC) services on a more solid basis. Several reform proposals have been under discussion since 2004, and in 2012 a working group with representatives from different ministries and stakeholders has been established to undertake detailed preparatory work regarding a comprehensive LTC reform (Nagode et al., 2014).

37. The current LTC system is rather complex, fragmented, and non-transparent. Long-term care is provided from within the general health and social care systems and paid for out of resources from the compulsory health insurance, the pension insurance, central and local government tax revenues, and private out-of-pocket contributions (about $25 \%$ of total LTC costs). Similarly, the regulations governing the sector are spread across several social security laws, and the oversight of LTC activities is split between the Ministry of Labour and the Ministry of Health. Patients often need to interact with different government services to claim benefits and might be subject to several differing needs assessments. A unifying framework is missing, social care and health care interventions are not always well coordinated, and there is an uneven regional distribution of LTC providers, with a notable undersupply in rural areas (Stanovnik and Prevolnik Rupel, 2013).

38. With expenditure on LTC as a share of GDP projected to more than double over the next 50 years (European Commission, 2015), developing an integrated care system and an adequate financing arrangement seems important to improve transparency and to better monitor the service quality and economic efficiency in the sector. Several types of funding arrangements have been under discussion (Dominkuš and Gracar, 2011). Proposals include schemes that break out a part of the compulsory health insurance and devote it to LTC, set up a private but compulsory LTC insurance, or introduce an LTC tax. Within the OECD, there has been a trend towards adopting a collectively financed system that provides universal eligibility for a basic package of care (Colombo et al., 2011), while leaving room for private top-up insurance (or out-of-pocket payments). A broader base for the LTC levy that does not only comprise the working-age population but also pensioners would thereby offer the advantage of mitigating the levy-induced increase in labour costs, ensuring greater funding stability, and enhancing the spirit of solidarity across generations.

39. LTC in Slovenia is currently oriented towards institutional care (Figure 16). As the latter is very expensive, a move towards home care is likely to generate substantial savings, while improving the quality of life of old people (OECD, 2013b). The government has already taken measures to further develop community-based services, such as day care centres and smaller residential units, and to unify health and social home care services. However, institutional care continues to benefit from higher public cost coverage and better services, while home care patients have to assume their living costs and have access to a more limited scope of care services. Also, home care patients often have access to only one service provider within their municipalities (Prevolnik Rupel et al., 2010), so that there is limited choice and competition. In some Northern European countries, patients have been receiving vouchers that they can use to contract those providers that offer a service package that bests suits their needs. The Slovenian authorities might want to explore this option as a cost-reducing and patient-friendly measure. 
Figure 16. Slovenia is oriented toward institutional long term care

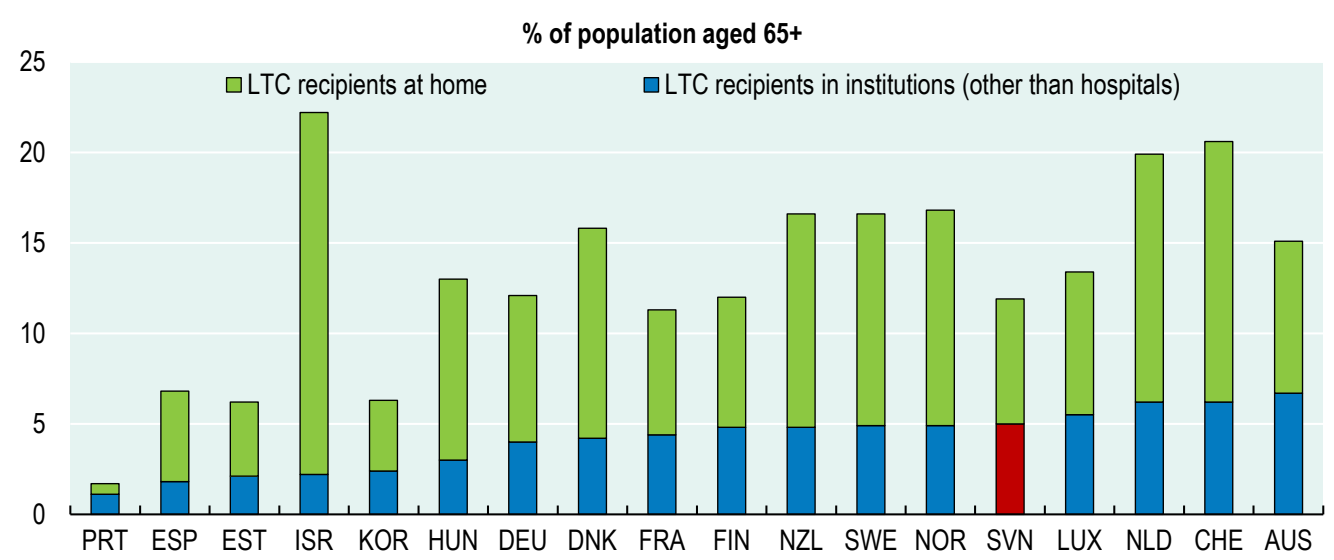

Source: OECD Long-Term Care Resources and Utilisation database.

40. Another weakness of the existing LTC-system in Slovenia that should be addressed in the context of the upcoming reform is lack of support for healthy and active ageing programmes. While life expectancy at 77 years for men and 83 years for women is above the EU average, the number of healthy life years is below the EU benchmark (Figure 17). Preventive and rehabilitative care is underdeveloped and so is the use of advanced information and communication technologies in LTC. Also, Slovenia does not have a single specialized palliative care facility. Investments in these areas would certainly improve the welfare of the elderly and might also help to contain LTC-costs.

Figure 17. Life expectancy (LE) and healthy life years (HLY) at birth, by gender, 2012
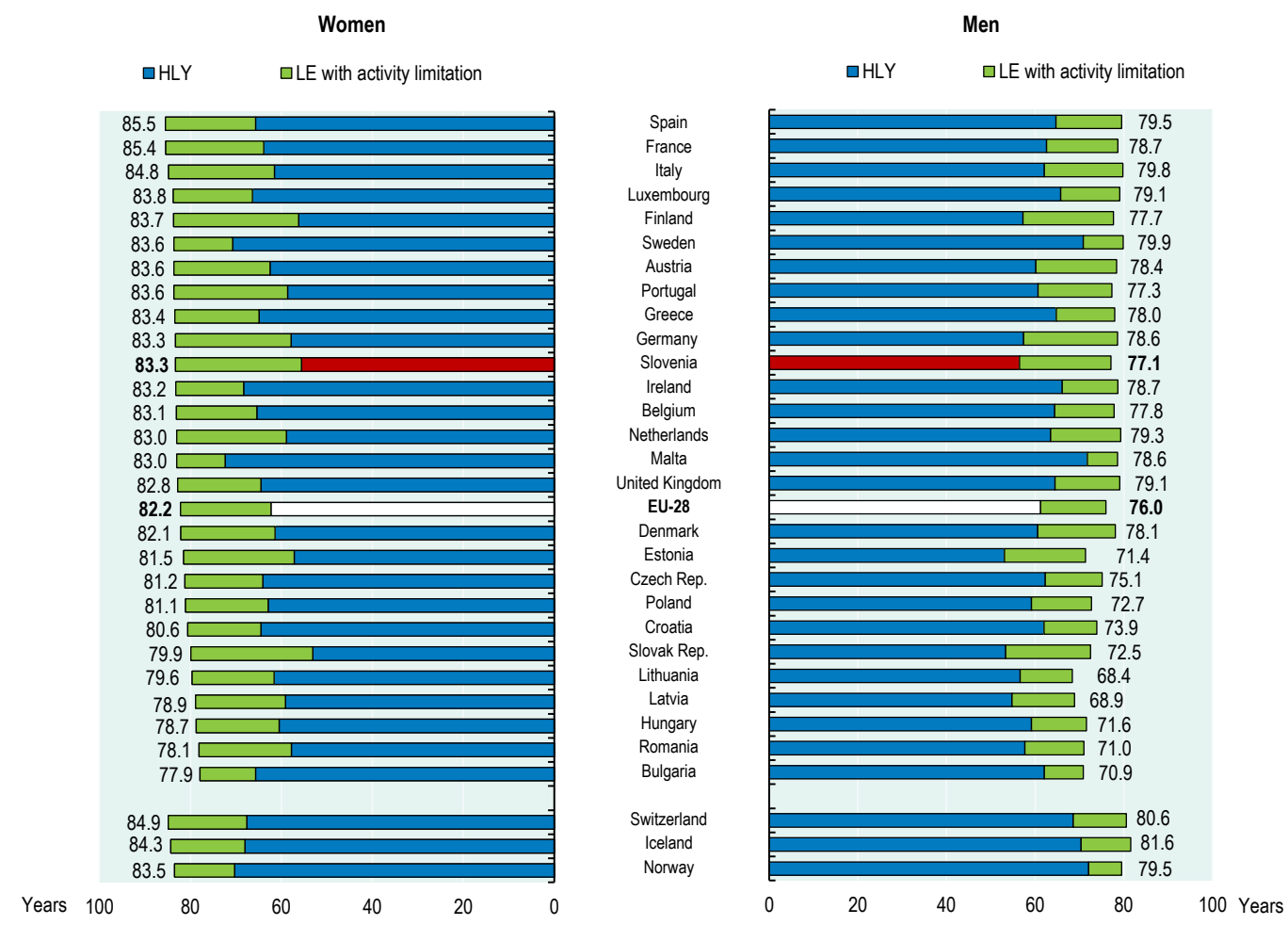

Source: OECD Health at a Glance: Europe 2014. 


\section{Demographic trends will have profound implications for the labour market}

41. The ageing of the population in Slovenia will also have marked effects on the labour market. As the cohort of the elderly expands, the active population shrinks in relative terms. The share of the working-age population (aged 15 to 64) in the total population in Slovenia is projected to fall by almost 15 percentage points by 2060, compared with a drop of less than 11 percentage points for the European Union as a whole. One remedy to counter this trend would naturally be for people to extend their working lives, as encouraged also with the 2013 pension reform. Yet, this represents a major challenge, since the labour force participation rate of older workers (aged 55-64) is currently very low in Slovenia. Indeed, it is the lowest in the European Union and the second lowest in the OECD (Figure 18). Getting older workers to remain professionally active will require strengthening financial incentives to continue working, tackling employment barriers on the side of employers, and improving the employability of older workers (OECD, 2006).

Figure 18. Labour force participation rate of older workers, 2013

$\%$ Population aged $55-64$

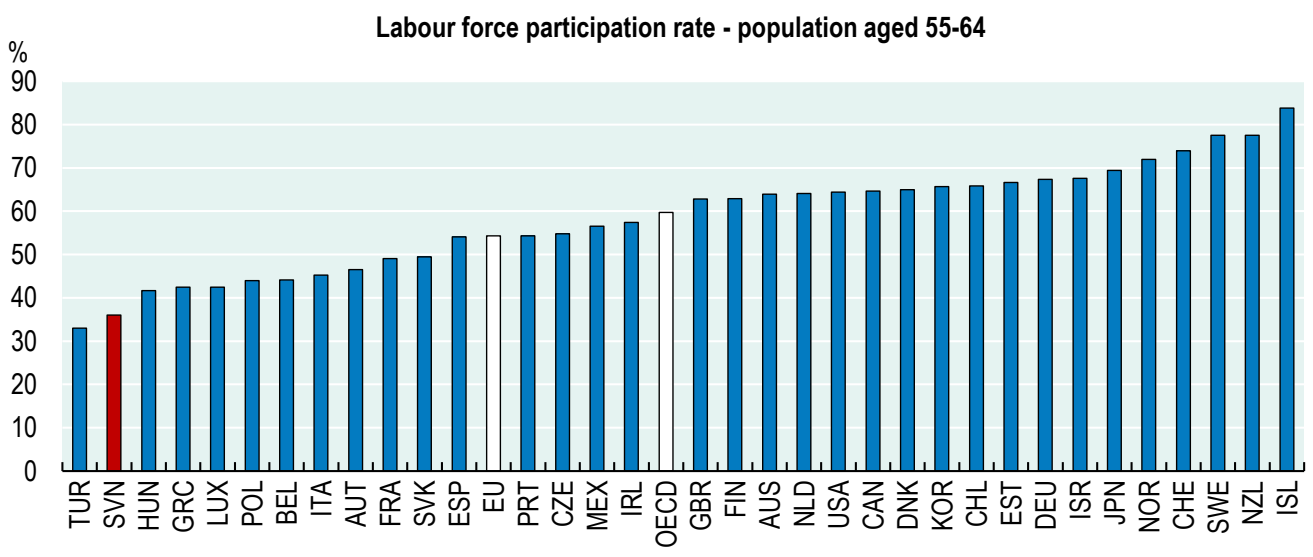

Source: OECD Short-term labour market statistics database.

42. Reducing explicit or implicit taxes on continued work will incentivise older people to remain in the active workforce. Slovenia used to have a very high implicit marginal tax on continued work (Kierzenkowski, 2013), which contributed to the very low labour force participation of older workers. Both the pension reform of 2013 and the labour market reform of 2013 contain measures to address this issue and encourage continued employment of older workers. In particular, the pension reform increases the statutory and minimum retirement ages and provides benefits in the form of higher pension pay-outs for continued work beyond the normal retirement age and penalties for early retirement. The labour market reform introduces the possibility of temporary work for pensioners. Moreover, during the financial crisis several targeted measures, including the partial exemption from payment of social security contributions, were introduced to encourage the hiring of older workers on a permanent basis.

43. The 2013 pension reform also tightened the requirements for early retirement. While the possibility to lower the statutory retirement age due to child care, compulsory military service or early career start was maintained, this pathway into early retirement is available only under conditions that are more restrictive than under the previous system. Yet, conditions to retire early could also be tightened for special pension regimes, such as those available to policemen, firemen, pilots, and miners (OECD, 2013b). 
44. Analysis using the OECD pension model suggests that the 2013 pension reform has strengthened to some extent the incentives for older workers to remain in the labour force. In particular, the net pension wealth of an individual from staying in a job is higher now than it used to be under the previous policy (Figure 19). The change in net pension wealth measures the level of the pension promise from remaining in employment for an additional year. The calculation is the annual average increase in males' pension wealth when working an additional year at age 55 to 59 (early retirement) or at age 60 to 64 (old-age pension). It represents the present value of the flow of pension benefits, taking account of the taxes and social security contributions that retirees have to pay on their pensions. It is affected by life expectancy and by the age at which people take their pensions, as well as indexation rules. The indicator is measured as a multiple of annual gross earnings.

\section{Figure 19. Changes in net pension wealth}

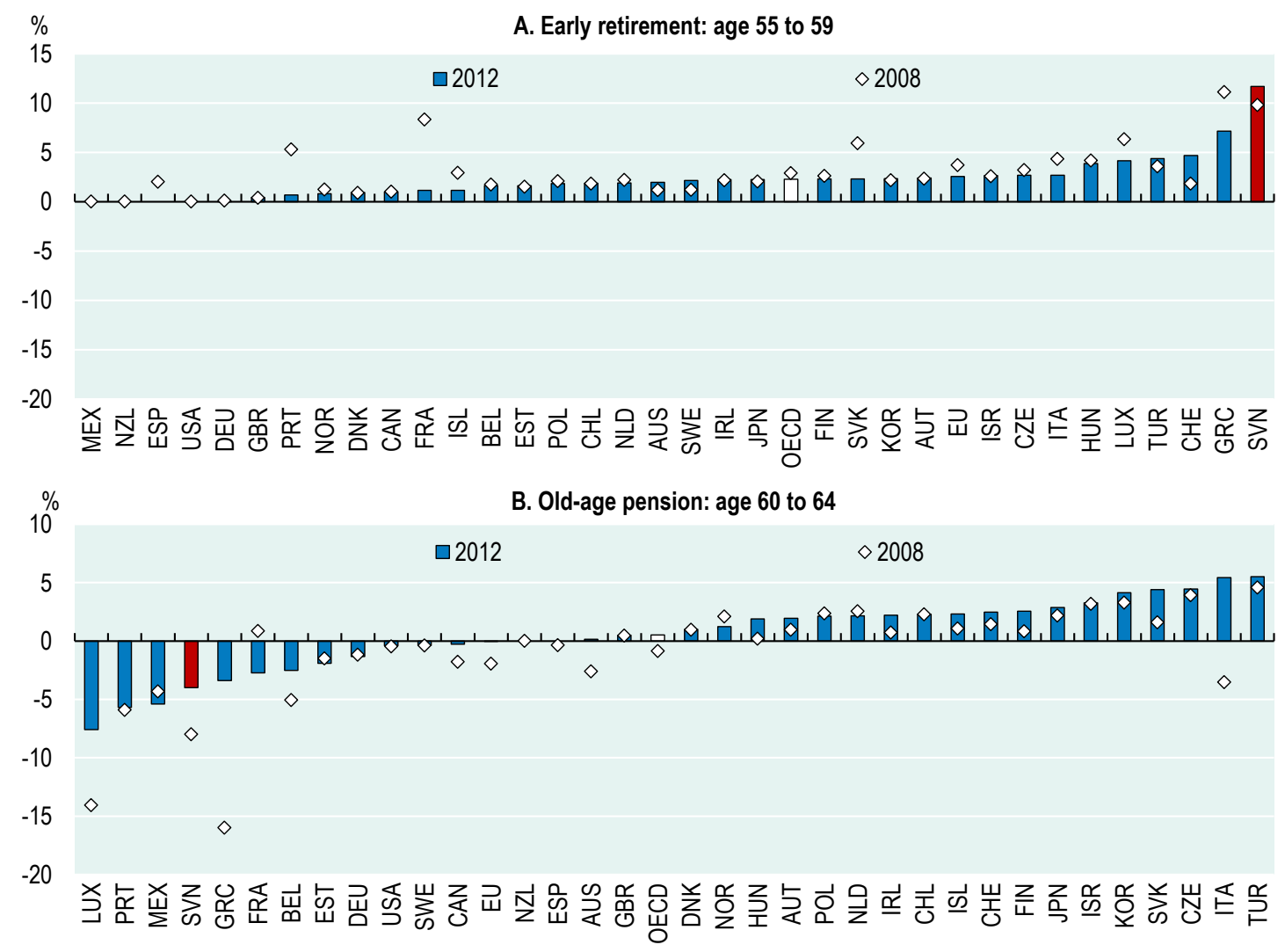

Note: The analysis labelled as 2012 is based on parameters and taxes for 2012, but long term legislated rules that were known at the time of publication are taken into account. In particular, the pension reform of 2013 for Slovenia is reflected in the calculations.

The change in pension wealth is a measure of the incentive to remain in the workforce for an additional period. It measures the level of the pension promise from remaining in employment for an additional year. The calculation is the annual average increase in males' pension wealth when working from age 55 to 59 (early retirement) and from age 60 to 64 (old-age pension). Net pension wealth is the present value of the flow of pension benefits, taking account of the taxes and social security contributions that retirees have to pay on their pensions. It is measured and expressed as a multiple of gross annual individual earnings in the respective country. See OECD (2013), Pensions at a Glance 2013: OECD and G20 Indicators for additional details.

Source: OECD Pension Models.

45. Indeed, in the age group of the 55 to 59 year olds, Slovenia provides the strongest incentives to remain in the labour force across all OECD countries. Conversely, beyond the age of 60 , there is relatively little benefit to stay in a job and an additional year of employment actually leads to a decline in net pension wealth. These findings are driven by the extension of the statutory contribution period to 40 years and the 
system of, respectively, penalties and bonuses that apply to early or deferred retirement. With a 40 year contribution period, an individual who is assumed to start work at age 20 can retire at a full pension at age 60. Every additional year of work then has relatively little impact on the pension level. There is a maximum $12 \%$ increase in the pension for three years of deferral, but this incentive is low by OECD standards and no additional benefit exists for working beyond three years. The actuarially neutral level of pension increases per year of additional work has been estimated at around 6-8\% for OECD countries (Queisser and Whitehouse, 2006). Hence, further incentives would be needed to entice older workers to stay active in the labour market.

46. Strict employment protection legislation can have both beneficial and detrimental effects on the employment rate of older workers. On the one hand, high dismissal costs may help to keep older workers in their job; while on the other hand, it raises the cost of hiring and thus may reduce the number of recruitments. The net impact is unclear, but some surveys have found that strict employment protection legislation tends to depress the hiring and retention rates of older workers (Daniel and Siebert, 2004; OECD, 2006). The 2013 labour market reforms were a decisive step in loosening dismissal legislation and Slovenia's legislation on employment protection is now just slightly more rigid than the average OECD country (Figure 20). This lowering of dismissal costs might also help to support the employment of older workers. Also, the reform introduced new measures, such as the gradual increase in the age from which workers benefit from special termination protection, that will also help increase the employability of older workers.

Figure 20. Protection of permanent workers against individual and collective dismissals, 2013

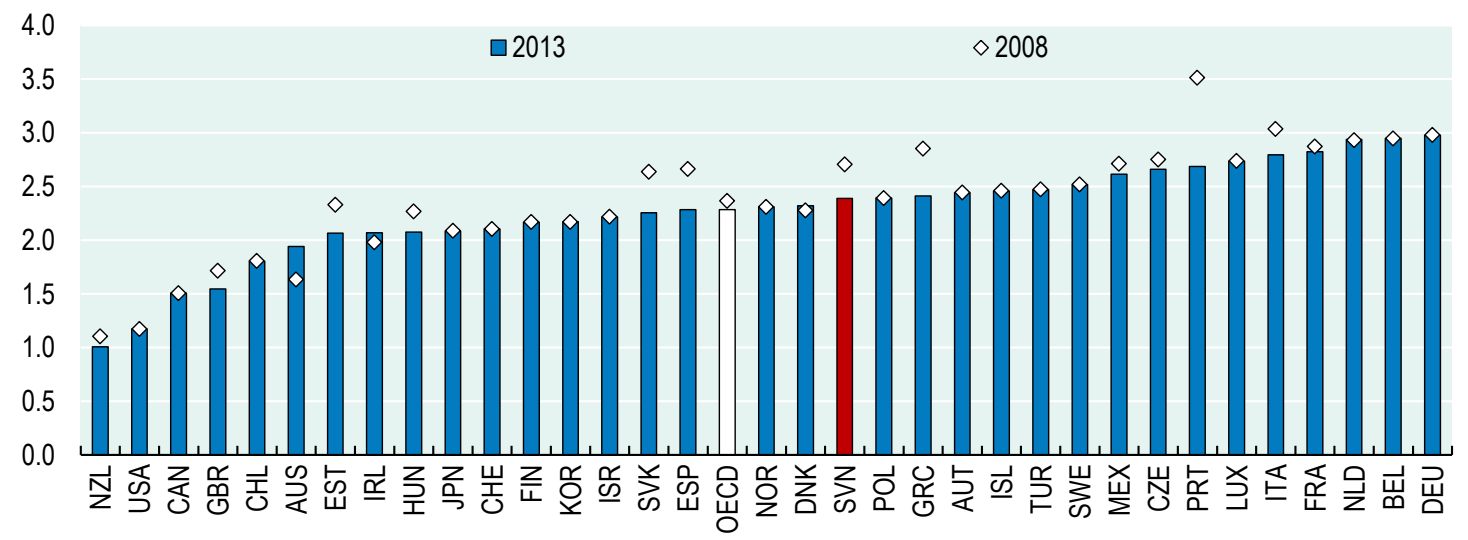

1. The OECD indicator of employment protection legislation (EPL) for regular employment measures the procedures and costs involved in dismissing individual regular employees. The indicator runs from 0 to 6 , representing the least to most restrictive EPL.

Source: OECD Employment Protection Database, 2013 update.

47. Yet, increasing the employment rate of older workers will also require overcoming the sometimes negative attitudes towards older workers and some misconceptions about their ability. Employers are often reluctant to hire older workers or retain them in their jobs because older employees are considered as having low technological skills, being slow in processing information, and lacking openness to new ideas (European Commission, 2012b). In Slovenia, age discrimination at work seems to be particularly pronounced (Figure 21). In this context, life-long learning and targeted training programs to older workers could help them adapt to new tasks and technologies and, thus, enhance their employability. Training can furthermore facilitate shifts of workers from arduous jobs to less exacting work after a certain age. In the same vein, programs that encourage employers to improve working conditions, so that the workplaces and working hours are more accommodating for older workers could encourage the latter to stay in the labour force for longer. 
Figure 21. Percentage of workers over 55 who report having been subject to age discrimination at work

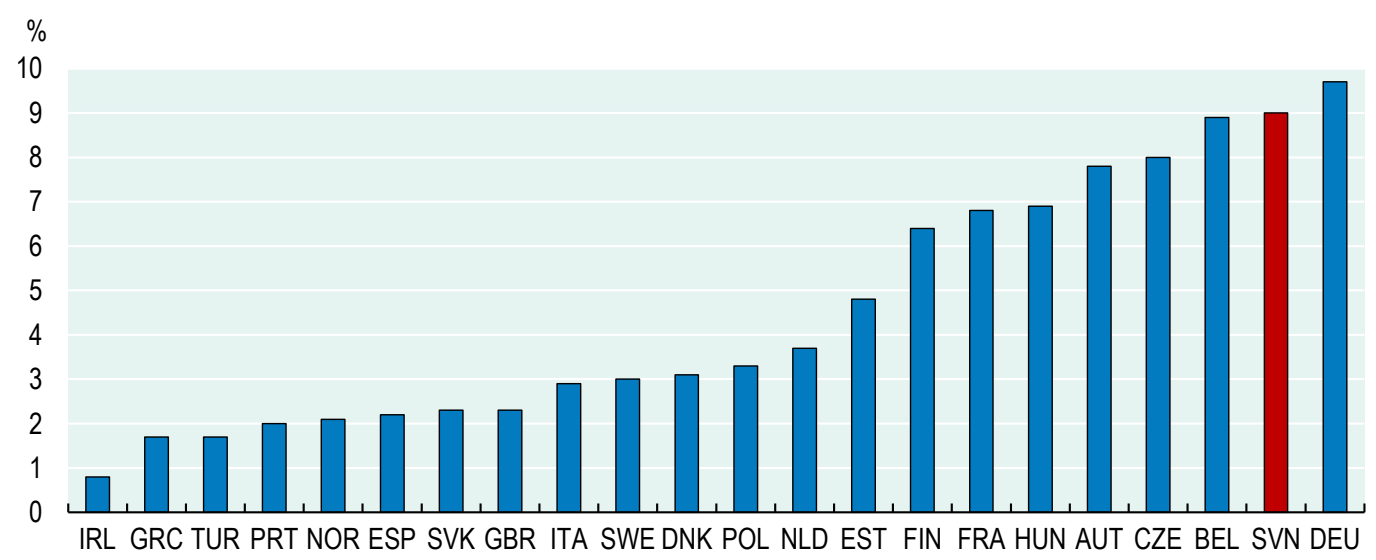

1. Percentage of workers over 55 years old who report having been subject to age discrimination at work. Source: European Working Conditions Survey, 2010.

48. In Slovenia, the Ministry of Labour, Family, Social Affairs and Equal Opportunities has been pursuing the "Employ.me" initiative since 2009 to promote the employment of disadvantaged unemployed individuals, including older persons. This active labour market policy provides employers with a EUR 5000 subsidy if they hire an individual from the target group for at least 12 months under full time working arrangements. The matching of disadvantaged unemployed individuals with the employers' job descriptions is done by the Employment Service of Slovenia, while the final selection of candidates is left to the employers. Over the period 2009-2013, about 15000 disadvantaged unemployed people found employment with the subsidy, including about 1500 individuals that were older than 55 years. For comparison, 102000 individuals were unemployed in 2013 (Eurostat - Labour market database). Half of those included in the Employ.me scheme were still employed with the same or another employer 12 months after the subsidy expired (MDDSZ, 2014b). Since 2009, approximately EUR 60 million have been paid to employers, of which $85 \%$ were co-financed by the European Social Fund.

\section{An ageing society also provides opportunities}

49. The ageing of the population in Slovenia will transform the society markedly and presents challenges across several dimensions, including income sustainability, social services, labour market adjustments, and infrastructure provision in rural areas. At the same time, the changing demographics also offer benefits and opportunities. For example, the elderly tend to be more law abiding, so that crime rates might fall. Older people are often positively inclined towards environmental protection, energy saving, and recycling initiatives, so that the resource footprint of the population might decrease. They also have spare time and are willing to volunteer and provide free or low-cost services to their communities.

50. Moreover, an ageing society provides market opportunities for firms that develop products and services for the elderly. The expanding health and long-term care sector will provide additional employment prospects and create business for supplementary services and products, from stair lifts to wheelchairs. Catering to a growing population of the elderly can help local enterprises to discover products and services that can subsequently be exported to other markets. Slovenia has a number of dynamic enterprises that produce goods and services for the elderly and seem well placed to benefit from the growing global market of senior customers. For example, a number of young companies in the Technology Park Ljubljana are focused on producing goods and services for the elderly, often using advanced information technology. For example, Socinet offers the communication platform LINKEDAGE, which provides networking access to social infrastructure and makes it possible for elderly individuals to remain 
independent for longer; Mobili provides tracking devices that can emit distress calls in the case of emergencies; MKS specializes in tele-care solutions for frail and disabled people living at home who need additional support for their independent living; MESI offers screening tools for peripheral arterial disease; and DRUGI specialises in developing mobile device interfaces for older or disabled individuals.

51. Many affluent pensioners have time to travel and enjoy holidays, including during off-peak periods. Slovenia's tourism sector seems well placed to cater to this group of customers. Tourism already accounts for about 5\% of GDP, employs more than 33000 workers, and contributes almost $40 \%$ to Slovenia's services exports (OECD, 2014d). Most inbound tourists come from Italy, Austria, Germany, Croatia, and Serbia - all nearby countries that will experience population ageing and will, hence, see the number of elderly increase over the coming decades. The World Travel and Tourism Council expects foreign tourist arrivals in Slovenia to increase by 3\% annually over the next ten years (WTTC, 2014). In order to exploit the elderly tourism market, Slovenian service providers in collaboration with the authorities will have to cater to the specific demands or older customers. For example, the latter often place a premium on good security and appreciate the existence of tourism-oriented policing units. Tourism locales will also want to review their physical structures for easy accessibility and ensure that the size of print that they use in information brochures is easy to read for ageing eyes. Finally, health-oriented offerings, such as wellness spas, are generally very much appreciated by older travellers.

\section{Recommendations on pensions, health care, long-term care, and labour market reforms}

\section{Key recommendations}

- Increase the statutory and minimum pension ages and link them explicitly to life expectancy. Calculate pension rights over lifetime contributions.

- Thoroughly reform the health sector to improve efficiency, including of organizational and governance structures and public procurement.

\section{Further recommendations}

- Increase the weight of inflation in the pension indexation rule.

- Revise the list of occupations for the supplementary occupational pension fund and set the contributions in line with actuarial principles.

- Strengthen the role of voluntary private pensions in order to complement the income of the elderly.

- Equalize the contribution rates of different population groups to the compulsory health insurance and move coverage for health-critical services from the voluntary complementary insurance to the compulsory insurance system.

- Ensure transparent and sufficient funding for long-term care, based on contributions from the working-age population and pensioners.

- Develop home care by creating a level playing field with institutional care in the accessibility to health services, and by giving patients more freedom to organise their own care.

- Help older workers adapt to new tasks and technologies through life-long learning and targeted training programmes, and facilitate shifts of workers from strenuous jobs to less extorting work after a certain age. 


\section{BIBLIOGRAPHY}

Colombo, F., A. Llena-Nozal, J. Mercier and F. Tjadens (2011), Help Wanted? Providing and Paying for Long-Term Care, OECD Publishing.

CPC (2014), Annual Report 2013, Commission for the Prevention of Corruption (in Slovenian).

Daniel, K. and W.S. Siebert (2004), "Does Employment Protection Reduce the Demand for Unskilled Labor?” IZA Discussion Papers, No. 1290.

De la Maisonneuve, C. and J. Oliveira Martins (2013), "A Projection Method for Public Health and LongTerm Care Expenditures", OECD Economics Department Working Papers, No. 1048, OECD Publishing.

Disney, R.F. and E.R. Whitehouse (1999), "Pension plans and retirement incentives”, Pension Reform Primer series, Social Protection Discussion Paper no. 9924, World Bank, Washington, D.C.

Dominkuš, D. and I. Gracar (2011), "Closing the Gap - In Search for Ways to Deal with Expanding Care Needs and Limited Resources", Comment Paper, Peer Review in Social Protection and Social Inclusion and Assessment in Social Inclusion, October.

European Commission (2015), The 2015 Ageing Report. Economic and Budgetary Projections for the EU28 Member States (2013-2060).

European Commission (2014), The 2015 Ageing Report. Underlying Assumptions and Projection Methodologies, European Economy, No. 8.

European Commission (2012a), The 2012 Ageing Report. Economic and Budgetary Projections for the 27 EU Member States (2010-2060), European Economy, No. 2.

European Commission (2012b), “Active Ageing”, Special Eurobarometer 378.

HelpAge International (2014), The Global AgeWatch Index: Insight Report.

IMF (2015), Republic of Slovenia: Selected Issues. IMF Country Report No. 15/42. Washington DC.

Kierzenkowski, R. (2013), "Restructuring Welfare Spending in Slovenia”, OECD Economics Department Working Papers, No. 1061, OECD Publishing.

Majcen B, M. Čok, J. Sambt, T. Turk, N. Stropnik, G. Dekkers, V. Prevolnik Rupel, V. Lavrac, N. Kump, M. Ogorevc (2012), "Izgradnja kombiniranega mikrosimulacijskega modela in modela generacijskih računov, Inštitut za ekonomska raziskovanja,” Ljubljana.

Ministry of Finance (2013), "Country Fiche on Pension Projections," Update for the peer review, Ljubljana.

Ministry of Health (2015), "Additional information and clarifications regarding waiting periods and eHealth," Follow-up after the meeting between the Ministry of Health and the European Commission, Ljubljana. 
Ministry of Labour, Family, Social Affairs and Equal Opportunities (MDDSZ) (2014a), "Učinki Pokojninske Reforme in Nadaljnji Koraki," Ljubljana.

Ministry of Labour, Family, Social Affairs and Equal Opportunities (MDDSZ) (2014b), “Zaposli.me/ Spodbujanje zaposlovanja težje zaposljivih brezposelnih oseb" http://ec.europa.eu/social/main.jsp?catId=1080\&langId=en\&practiceId=30.

Ministry of Labour, Family, Social Affairs, and Equal Opportunities (2013), “Additional Clarification on Article 23 - The right of elderly persons to social protection - in respect of the question posed by the European Committee of Social Rights," Document RAP/RCha/SLO/12(2013)Add, European Social Charter.

Nagode M., E. Zver, S. Marn, A. Jacović, D. Dominkuš (2014), Long-term care - use of the international definition in Slovenija, IMAD Working Paper 2/2014, Vol. XXIII.

OECD (2014a), "Growth Prospects and Fiscal Requirements Over the Long Term", in OECD, OECD Economic Outlook, Volume 2014 Issue 1, OECD Publishing, Paris.

DOI: http://dx.doi.org/10.1787/eco_outlook-v2014-1-44-en.

OECD (2014b), OECD Pensions Outlook 2014, OECD Publishing, Paris. DOI: http://dx.doi.org/10.1787/9789264222687-en.

OECD (2014c), Slovenia: Reforms for a Strong and Sustainable Recovery, Better Policies, OECD Publishing, Paris. DOI: http://dx.doi.org/10.1787/9789264215894-en

OECD (2014d), "Slovenia", in OECD, OECD Tourism Trends and Policies 2014, OECD Publishing, Paris. DOI: http://dx.doi.org/10.1787/tour-2014-35-en

OECD (2013a), Pensions at a Glance 2013: OECD and G20 Indicators, OECD Publishing, Paris. DOI: http://dx.doi.org/10.1787/pension_glance-2013-en

OECD (2013b), OECD Economic Surveys: Slovenia 2013, OECD Publishing, Paris. DOI: http://dx.doi.org/10.1787/eco_surveys-svn-2013-en

OECD (2011a), Pensions at a Glance 2011: Retirement-income Systems in OECD and G20 Countries, OECD Publishing, Paris.

DOI: http://dx.doi.org/10.1787/pension_glance-2011-en

OECD (2011b), Slovenia: Review of the Private Pension System, OECD Publishing.

OECD (2006), Live Longer, Work Longer, OECD Publishing, Paris.

DOI: http://dx.doi.org/10.1787/9789264035881-en

Oliveira Martins, J. and de la Maisonneuve, C. (2014), "The Future of Health and Long-Term Care Spending”, OECD Journal: Economic Studies, OECD Publishing.

Prevolnik Rupel, V., M. Ogorevc and B. Majcen (2010), “The Long-Term Care System for the Elderly in Slovenia", ENEPRI Research Report No. 87, European Network of Economic Policy Research Institutes. 
Queisser, M. and E.R. Whitehouse (2006), "Neutral or Fair? Actuarial Concepts and Pension-System Design”, OECD Social, Employment and Migration Working Papers, No. 40, OECD Publishing, http://dx.doi.org/10.1787/351382456457.

Stanovnik, Tine, and Valentina Prevolnik Rupel (2013), "Pensions, health and long-term care: Slovenia," ASISP country document, Brussels.

Van Erp, F., N. Vermeer and D. van Vuuren (2013), "Non-Financial Determinants of Retirement”, CPB Discussion Paper No. 243.

World Health Organization (2011), Global Health and Ageing, Geneva.

World Travel and Tourism Council (2014), Travel and Tourism Impact 2014: Slovenia, London. 


\section{WORKING PAPERS}

The full series of Economics Department Working Papers can be consulted at www.oecd.org/eco/workingpapers

1241. Raising competitiveness and long-term growth of the Slovenian economy

(June 2015) by Urban Sila, Nataša Jemec and Hermes Morgavi

1240. Frontier firms, technology diffusion and public policy: micro evidence from OECD countries (June 2015) by Dan Andrews, Chiara Criscuolo and Peter N. Gal.

1239. Luxembourg - addressing new challenges in a major financial sector

(June 2015) by Eckhard Wurzel and Damien Azzopardi

1238. Productivity spillovers from the global frontier and public policy: industry level evidence (June 2015) by Alessandro Saia, Dan Andrews and Silvia Albrizio

1237. The stabilisation properties of immovable property taxation: evidence from OECD countries (May 2015) by Hansjörg Blöchliger, Balázs Égert, Bastien Alvarez and Aleksandra Paciorek

1236. Making the most of natural resources in Indonesia

(May 2015) by Richard Dutu

1235. Reforming the pension system to increase coverage and equity in Colombia.

(May 2015) by Christine de la Maisonneuve

1234. Making Colombia's tax policy more efficient, fair and green

(May 2015) by Christian Daude, Sarah Perret and Bert Brys

1233. Skills and labour market performance in Sweden

(May 2015) by Margherita Bussi and Jon Kristian Pareliussen

1232. Skills and inclusive growth in Sweden

(May 2015) by Jon Kristian Pareliussen, Margherita Bussi, Christophe André and Vincent Koen

1231. Incorporating anchored inflation expectations in the Phillips Curve and in the derivation of OECD measures of equilibrium unemployment

(May 2015) by Elena Rusticelli, David Turner and Maria Chiara Cavalleri

1230. Macroeconomic uncertainties, prudent debt targets and fiscal rules,

(July 2015) by Falilou Fall and Jean-Marc Fournier

1229. Limits to government debt sustainability

(July 2015) by Jean-Marc Fournier and Falilou Fall

1228. Government debt indicators: understanding the data

(July 2015) by Debbie Bloch and Falilou Fall

1227. The costs of flexibility-enhancing structural reforms: a literature review

(July 2015) by Tito Boeri, Pierre Cahuc and André Zylberberg 
1226. Household finance and income inequality in the euro area

(June 2015) by Oliver Denk and Alexandre Cazenave-Lacroutz

1225. Financial sector pay and labour income inequality: evidence from Europe

(June 2015) by Oliver Denk

1224. Finance and income inequality in OECD countries

(June 2015) by Oliver Denk and Boris Cournède

1223. Finance and economic growth in OECD and G20 countries

(June 2015) by Boris Cournède and Oliver Denk

1222. What impedes household investment in energy efficiency and renewable energy?

(May 2015) by Nadia Ameli and Nicola Brandt

1221. Recent trends in productivity in China - shift-share analysis of labour productivity growth and the evolution of the productivity gap

(May 2015) by Margit Molnar and Thomas Chalaux

1220. Assessing China's skills gap and inequalities in education

(May 2015) by Margit Molnar, Boqing Wang and Ruidong Gao

1219. Providing the right skills to all in China - from "made in China" to "created in China"

(May 2015) by Margit Molnar and Vincent Koen

1218. Agricultural reforms and bridging the gap for rural China

(May 2015) by Ben Westmore

1217. A snapshot of China's service sector

(May 2015) by Margit Molnar and Wei Wang

1216. Does the post-crisis weakness of global trade solely reflect weak demand?

(May 2015) by Patrice Ollivaud and Cyrille Schwellnus

1215. Estonia: raising productivity and benefitting more from openness

(May 2015) by Andreas Kappeler

1214. Estonia: making the most of human capital

(May 2015) by Andrés Fuentes Hutfilter

1213. The Czech labour market: documenting structural change and remaining challenges

(May 2015) by Sónia Araújo and Petr Malecek

1212. Reforming the Slovak public sector

(April 2015) by Lilas Demmou and Robert Price

1211. Spurring growth in lagging regions in the Slovak Republic

(April 2015) by Lilas Demmou, Gabriel Machlica, Martin Haluš and Robert Menkyna

1210. Skill mismatch and public policy in OECD countries

(April 2015) by Müge Adalet McGowan and Dan Andrews 